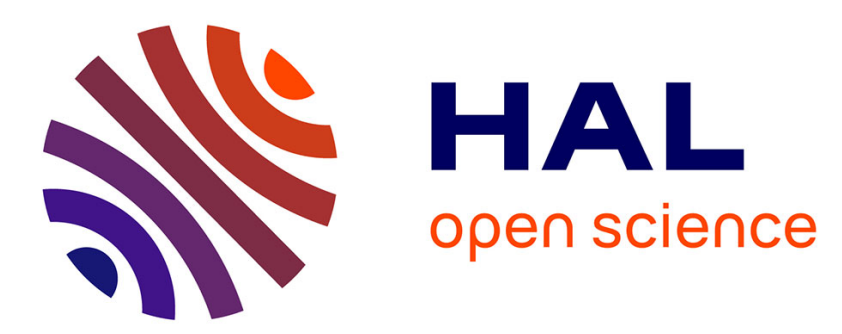

\title{
Diffusion of phenolic compounds through polyethylene films
}

\author{
M. Mendes, N. Touze Foltz, M. Gardoni, L. Mazéas
}

\section{To cite this version:}

M. Mendes, N. Touze Foltz, M. Gardoni, L. Mazéas. Diffusion of phenolic compounds through polyethylene films. Geosynthetics International, 2014, 21 (2), pp.137-150. 10.1680/gein.14.00005 . hal-01493796

\section{HAL Id: hal-01493796 \\ https://hal.science/hal-01493796}

Submitted on 22 Mar 2017

HAL is a multi-disciplinary open access archive for the deposit and dissemination of scientific research documents, whether they are published or not. The documents may come from teaching and research institutions in France or abroad, or from public or private research centers.
L'archive ouverte pluridisciplinaire HAL, est destinée au dépôt et à la diffusion de documents scientifiques de niveau recherche, publiés ou non, émanant des établissements d'enseignement et de recherche français ou étrangers, des laboratoires publics ou privés. 


\title{
Diffusion of phenolic compounds through polyethylene films
}

\author{
M. Mendes ${ }^{1}$, N. Touze-Foltz ${ }^{2}$, M. dG. Gardoni ${ }^{3}$ and L. Mazéas ${ }^{4}$ \\ ${ }^{1}$ Post-doctorate student, Irstea, HBAN Research Unit, 1 Rue Pierre-Gilles de Gennes, CS 1003092761 \\ Antony Cedex, France, Telephone: +33140966039, Telefax: +331409662 70, \\ E-mail: marianna.mendes@irstea.fr \\ ${ }^{2}$ Head of the Geosynthetics Team, Irstea, HBAN Research Unit, 1 rue Pierre-Gilles de Gennes, CS \\ 1003092761 Antony Cedex, France, Telephone: +33140966039, Telefax: +331409662 70; \\ E-mail: nathalie.touze@irstea.fr \\ ${ }^{3}$ Professor, Universidade Federal de Minas Gerais - UFMG Escola de Engenharia da UFMG \\ Departamento de Engenharia de Transportes e Geotecnia - DETG Av. Pres. Antônio Carlos 6627, \\ Bloco 1, 3 Andar, Sala 3602 - Campus UFMG 31.270-901 Belo Horizonte - MG, Brazil, \\ Telephone: +55 31 34091747, Telefax:+55 31 34091793,E-mail: gardoni@etg.ufmg.br \\ ${ }^{4}$ Researcher, Irstea, HBAN Research Unit, 1, Rue Pierre-Gilles de Gennes, CS 10030, 92761 Antony \\ Cedex, France, Telephone: +33140966061, Telefax: +331409662 70, \\ E-mail: laurent.mazeas@irstea.fr
}

Received 24 October 2013; revised 20 January 2014; accepted 30 January 2014

\begin{abstract}
This paper presents experimental results of the diffusion of phenolic compounds through virgin and aged polyethylene (PE) films. The study considers five chlorophenols contaminants (4-chlorophenol, 2,4-dichlorophenol, 2,4,6-tricholophenol, 2,3,5,6-tetrachlorophenol, and pentachlorophenol) that are known to be toxic even at very low concentrations. The concentration dynamics in the source and receptor chambers of the diffusion cells is interpreted using the numerical code Pollute. For virgin PE film, partition coefficients ranged from 0.68 to 278 , which corresponded to 4-chlorophenol and pentachlorophenol, respectively. Diffusion coefficients ranged from $1.0 \times 10^{-14}$ to $2.7 \times 10^{-13} \mathrm{~m}^{2} / \mathrm{s}$, which corresponded to pentachlorophenol and 2,4dichlorophenol, respectively. The study also looked at how the partition and diffusion coefficients were affected by the aqueous solubility, $n$-octanol-water partition coefficient, molecular diameter, and molecular weight. The trends observed in this study are similar to those found for diffusion of phenolic compounds through PE geomembranes. The results also revealed trends that differ from those previously reported for diffusion of volatile organic compounds (VOCs) through geomembranes. The existing empirical relationships for VOCs are not applicable except for calculating how the diffusion coefficient evolves as a function of solubility in water. Increasing the number of chlorine atoms on the phenolic nucleus causes an increase in the partition coefficient, which is tentatively attributed to the polarity of the molecules under study.
\end{abstract}

KEYWORDS: Geosynthetics, Diffusion, Partition, Phenolic compounds, PE film, Ageing REFERENCE: Mendes, M., Touze-Foltz, N., Gardoni, M. dG. and Mazéas, L. (2014). Diffusion of phenolic compounds through polyethylene films. Geosynthetics International, 21, No. 2, 137-150. [http://dx.doi.org/10.1680/gein.14.00005]

\section{INTRODUCTION}

Impermeable liners in landfills aim to limit soil and atmosphere contamination due in particular to microorganic pollutants present in municipal solid waste leachate. These pollutants can have toxic effects (acute toxicity, genotoxicity, reproductive toxicity, etc.) (Sisinno et al. 2000; Takigami et al. 2002) and their presence in leachate from municipal solid waste landfills has been clearly demonstrated in several countries (Oman and Hynning 1993; Ahel and Tepic 2000; Robinson et al. 2001; Hiroshi et al. 2002).
The most frequently encountered organic micropollutants in leachate are monoaromatic hydrocarbons (benzene, toluene, ethylbenzene, xylene) and polyaromatic hydrocarbons (naphthalene, phenanthrene, etc.). Some chlorinated solvents (trichlorethylene, chloromethane, etc.), plasticisers (phthalates, bisphenol A (BPA), etc.), pesticides, and phenolic derivatives are also found in leachate (Harmsen 1981; Bauer and Herrmann 1997; Staples et al. 1998; Gron et al. 1999; Christensen et al. 2001; Cousins et al. 2002; Kjeldsen et al. 2002; Niederer and Goss 2008; Van Praagh et al. 2011). 
Phenolic compounds, and in particular certain derivatives of halogenated phenolic compounds, are known to be toxic to humans and the environment even at very low concentrations. These compounds are used as disinfectants, biocides, preservatives, dyes, pesticides, and organic chemicals in medicine and industry (Ramamoorthy and Ramamoorthy 1997; Kujawski et al. 2004; Otero et al. 2005).

Geomembranes are widely used in geoenvironmental applications where they act as a barrier to prevent water and contaminants from entering the environment. A number of studies regarding the use of geomembranes have focused on the diffusion of sodium chloride (Rowe et al. 1995) or volatile organic compounds (VOCs) for virgin high-density polyethylene (HDPE) geomembranes (Park and Nibras 1993; Prasad et al. 1994; Müller et al. 1998; Sangam and Rowe 2001; Park et al. 2012), virgin polyvinyl chloride (PVC), linear low-density polyethylene with and without coextruded ethylene vinyl-alcohol innercore geomembranes (McWatters and Rowe 2008, 2010), fluorinated HDPE geomembranes (Sangam and Rowe 2005), and aged HDPE geomembranes (Rowe et al. 2003; Islam and Rowe 2008, 2009).

Regarding organic micropollutants other than VOCs, Touze-Foltz et al. (2012) studied the diffusion of phenolic compounds (phenol, o-cresol, $p$-cresol, 2,4-xylenol, 3,4-xylenol, 2-chlorophenol, 4-chlorophenol (4-CP), 2,4-dichlorophenol (2,4-DCP), 2,4,6-trichorophenol (2,4,6TCP), 2,3,4,6-tetrachlorophenol, 2,3,5,6-tetrachlorophenol (2,3,5,6-TeCP), pentachlorophenol (PCP) and BPA) through a $2 \mathrm{~mm}$-thick virgin HDPE geomembrane. The diffusion of phenolic compounds through geosynthetic clay liners was also studied (Mendes et al. 2013).

To study how ageing affects diffusive transfer through a geomembrane, virgin and aged samples of a single geomembrane must be obtained. However, the estimated time necessary for geomembranes to present significant degradation due to ageing is quite long at temperatures representative of field conditions, which makes it difficult to obtain appropriate samples. Indeed, a review of the subject by Pons (2012) finds only a limited number of studies on the durability of geomembranes. In some of these studies, specimens were aged in the laboratory or in situ and then submitted to mechanical testing. Other researchers cited by Pons (2012) considered adsorption and diffusion through aged geomembranes. For these studies, the experiments were directly related to the barrier function of the geomembrane. However, no comparisons with the corresponding virgin sample were possible because of the absence of control samples. Thus, there are currently too few studies of how ageing affects the ability of geomembranes placed at the bottom of municipal solid waste landfills to serve as a barrier to pollutants.

In this context, one of the objectives of the Durageos project (Farcas et al. 2013), which was developed in partnership with several laboratories and landfill owners, was to verify how ageing affects the capacity of geosynthetics to serve as barriers. Without an aged geomembrane sample and an associated control sample, the Durageos project used films specially designed for the research.
According to Pons (2012) and Pons et al. (2012), films thinner $(0.3 \mathrm{~mm}$ on average) than a geomembrane but made from the same polymer as the geomembrane allow one to: (i) obtain virgin and aged specimens of polyethylene (PE) films under controlled conditions in the laboratory; and (ii) compare the diffusion of micro-organic pollutants through aged and virgin specimens of PE films.

Therefore, the objective of the present study was to see how ageing of PE films affects diffusive transfer of chlorophenols. This study compares the diffusion of phenolic compounds through virgin and aged PE films. The results of experiments involving chlorophenols diffusing through PE films are compared with those obtained by Touze-Foltz et al. (2012) for phenolic compounds diffusing through a HDPE geomembrane. The results are also compared with those of the diffusion of VOCs through HDPE geomembranes.

\section{MATERIALS AND METHODS}

\subsection{Polyethylene films}

\subsubsection{Fabrication}

The PE films studied herein were produced from the same base resin as commercially available HDPE geomembranes in Europe; namely, a copolymer of polyethyleneoctene that was obtained in the form of pellets containing process stabilisers (antioxidants effective at high temperatures). For the resin, the molar mass in number $\left(M_{\mathrm{n}}\right)$ and in weight $\left(M_{\mathrm{w}}\right)$ as determined by 'ultrahigh temperature' gas phase chromatography, are $M_{\mathrm{n}}=44.1 \mathrm{~kg} / \mathrm{mol}$ and $M_{\mathrm{w}}=136.7 \mathrm{~kg} / \mathrm{mol}$. The density of $\mathrm{PE}$ is equal to 0.911 and the rate of crystallinity to $51 \%$. The films were fabricated from pellets by using a Gibritte Instrument press. The pressing conditions were those of Farcas et al. (2013). The method consists of heating the plates from the press to $200^{\circ} \mathrm{C}$. The heated plates were protected by cooking paper that protects the PE films during the process. Next, a pressure of $3 \mathrm{MPa}$ was applied for $10 \mathrm{~s}$, then $30 \mathrm{MPa}$ for $30 \mathrm{~s}$.

On average, $3 \mathrm{~g}$ of $\mathrm{PE}$ were used to make each film. Each film was $0.3 \mathrm{~mm}$ thick on average and had diameters ranging from 0.17 to $0.19 \mathrm{~m}$. Figure 1 shows a specimen of PE film.

\subsubsection{Ageing of PE film}

Ageing is any phenomenon contributing to slow and irreversible evolution of the structure or composition of a material and that results from the material's own instability, interaction with the environment, mechanical solicitations, or combined effects (Verdu 1984). Polymers are affected by two types of ageing: chemical ageing and physical ageing (morphological ageing). In the first case, the chemical structures of macromolecules are modified; in the second case, there is no alteration of the chemical structure, only the spatial configuration of the material is affected. In practice, chemical ageing is superimposed on physical ageing (Farcas et al. 2013).

Some PE film specimens fabricated as described in Section 2.1.1 were aged by thermo-oxidation at $105^{\circ} \mathrm{C}$, 


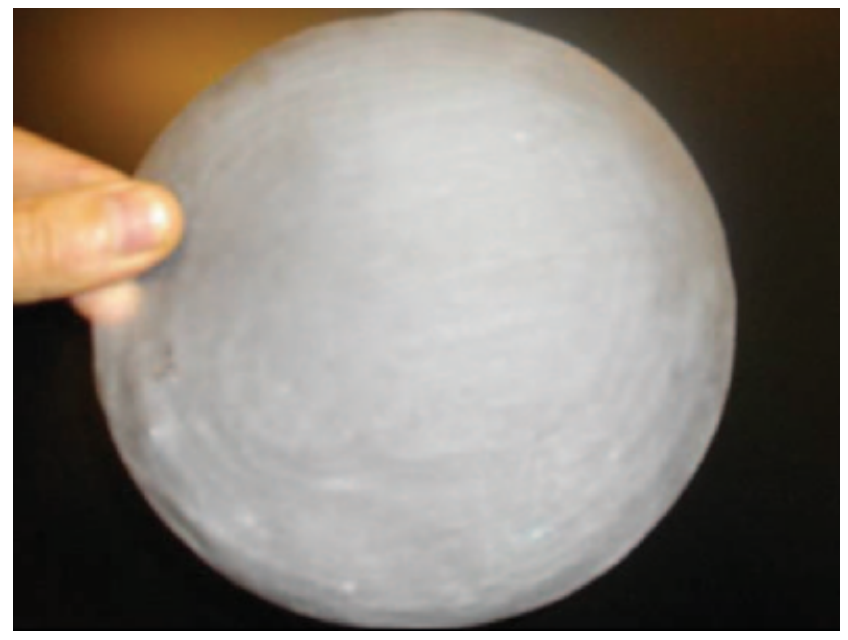

Figure 1. PE film specimen

which leads to the formation of carbonyl compounds (alcohols, carboxylic acids, etc.) and to an expected increase in the crystallinity. The final carbonyl concentrations in the oxidised samples were between 0.1 and $0.4 \mathrm{~mol} / \mathrm{kg}$ obtained after $300 \mathrm{~h}$ of thermo-oxidation (Pons 2012). For this carbonyl concentration, the crystallinity ranged from 54 to $66 \%$ according to the calibration curve proposed by Pons (2012) for the same polymer as that used in this study. These results are to be compared with $51 \%$ for virgin $\mathrm{PE}$.

The main features of the PE films tested (virgin or aged) are presented in Table 1. For virgin specimens, duplicate diffusion experiments were performed in independent cells. Only a single aged specimen was tested.

\subsection{Phenolic compounds}

\subsubsection{Description of the phenolic compounds under} study

The adsorption characteristics of five phenolic compounds are reported in this paper: 4-CP, 2,4-DCP, 2,4,6-TCP,
2,3,5,6-TeCP and PCP. Various physical and chemical properties of the selected compounds are given in Table 2. The chemical solution used to measure diffusion contained the same 13 phenolic compounds used by Touze-Foltz et al. (2012). From among these 13 compounds, only the results of the five compounds mentioned above were analysed.

All chlorophenols studied were in the solid state and at ambient temperature $\left(23^{\circ} \mathrm{C}\right)$. Their boiling points are between 188 and $300^{\circ} \mathrm{C}$. In general, these compounds dissolve poorly in water, but well in organic solvents.

As mentioned by Ahari et al. (2011), the octanol-water partition coefficient, $K_{\text {ow }}$, of the pollutants under study in this paper strongly increases with the number of chlorine atoms whereas the water solubility (hydrophilicity) decreases. Furthermore, the degree of dissociation of chlorophenols increases (indicated by decreasing $\mathrm{p} K_{\mathrm{a}}$ values) with increasing number of chlorine atoms. It is thus expected that any differences between the properties of the various phenolic compounds would lead to differences in diffusion through the PE films studied in this paper.

The phenolic compounds were selected using the following criteria: (1) polarity; (2) solubility in water; (3) mobility of pollutants in soils; (4) presence in leachate; and (5) toxicity. Concentrations were chosen based on (1) a literature review to determine minimum, maximum, and average concentrations in leachate of the selected phenolic compounds (see Table 3) (Reinhard and Goodman 1984; Sawhney and Kozloski 1984; Oman and Hynning 1993; Schrab et al. 1993; Nininen and Kalliokoski 1994; Yasuhara et al. 1997; Lee et al. 1998; Viraraghavan and Alfaro 1998; Yamada et al. 1999; Yasuhara et al. 1999; Banat et al. 2000; Paxeus 2000; Behnisch et al. 2001; Yamamoto et al. 2001; Koumanova and Peeva-Antova 2002; Ribeiro et al. 2002; Reitzel and Ledin 2002; Schwarzbauer et al. 2002; Baun et al. 2004; Nagasaki et al. 2004; Yu et al. 2004; Ozkaya 2005; Slack et al. 2005; Richards and Bouazza 2007) and (2) the limit of detection

Table 1. Characteristics of specimens of PE films tested

\begin{tabular}{|l|c|c|c|c|c|}
\hline $\begin{array}{l}\text { Specimen } \\
\text { no. }\end{array}$ & $\begin{array}{c}\text { Mass } \\
(\mathrm{g})\end{array}$ & $\begin{array}{c}\text { Thickness } \\
(\mathrm{mm})\end{array}$ & Density & $\begin{array}{c}\text { Specimen } \\
\text { condition }\end{array}$ & Crystallinity (\%) \\
\hline 1 & 6.45 & 0.314 & 0.911 & virgin & 51 \\
2 & 5.34 & 0.316 & 0.911 & & aged \\
3 & 5.20 & 0.299 & 0.911 & 54 to 66 \\
\hline
\end{tabular}

Table 2. Physical and chemical properties of chlorophenol compounds under study (Touze-Foltz et al. 2013)

\begin{tabular}{|l|c|c|c|c|c|}
\hline Contaminants & Formula & $\begin{array}{c}\text { Molecular weight } \\
(\mathrm{g} / \mathrm{mol})\end{array}$ & $\begin{array}{c}\text { Solubility } \mathrm{g} / \mathrm{l} \\
\left(\text { at } 20^{\circ} \mathrm{C}\right)\end{array}$ & $\mathrm{p} K_{\mathrm{a}}$ & Log $K_{\mathrm{ow}}$ \\
\hline Chlorophenols & $\mathrm{C}_{6} \mathrm{H}_{5} \mathrm{ClO}$ & 128.56 & 27 & 9.37 & 2.53 \\
\hline 4-CP & $\mathrm{C}_{6} \mathrm{H}_{4} \mathrm{Cl}_{2} \mathrm{O}$ & 163.00 & 4.5 & 7.90 & 3.20 \\
$2,4-\mathrm{DCP}$ & $\mathrm{C}_{6} \mathrm{H}_{3} \mathrm{Cl}_{3} \mathrm{O}$ & 197.45 & 0.434 & 6.00 & 3.67 \\
$2,4,6-\mathrm{TCP}$ & $\mathrm{C}_{6} \mathrm{H}_{2} \mathrm{Cl} \mathrm{O}$ & 231.89 & 0.100 & 5.02 & 5.02 \\
$2,3,5,6-\mathrm{TeCP}$ & $\mathrm{C}_{6} \mathrm{Cl}_{5} \mathrm{OH}$ & 266.34 & 0.014 & 4.74 & 5.85 \\
PCP & &
\end{tabular}


Table 3. Concentrations used for experiments (Ahari et al. 2011)

\begin{tabular}{|l|c|c|c|c|c|c|}
\hline Contaminants & $\begin{array}{c}\text { Min. value } \\
(\mu \mathrm{g} / \mathrm{l})\end{array}$ & $\begin{array}{c}\text { Max. value } \\
(\mu \mathrm{g} / \mathrm{l})\end{array}$ & $\begin{array}{c}\text { Mean value } \\
(\mu \mathrm{g} / \mathrm{l})\end{array}$ & $\begin{array}{c}\text { Corrected mean } \\
(\mu \mathrm{g} / \mathrm{l})\end{array}$ & $\begin{array}{c}\text { LOD (ng/l) } \\
\text { Concentration } \\
(\mu \mathrm{g} / \mathrm{l})\end{array}$ \\
\hline 4-CP & 0.070 & 1.300 & 0.611 & 0.611 & 25 & 1.04 \\
2,4-DCP & 0.010 & 12.820 & 1.026 & 0.30 & $1.11 \times 10^{-3}$ & 10 \\
$2,4,6-\mathrm{TCP}$ & 0.002 & 1.870 & 0.162 & 0.065 & $1.15 \times 10^{-3}$ & 10 \\
$2,3,5,6-\mathrm{TeCP}$ & 0.012 & 0.012 & 0.012 & 0.012 & 1.07 & 10 \\
PCP & 0.015 & 21.610 & 3.798 & 0.83 & 10 \\
\hline
\end{tabular}

(LOD) and limit of quantification (LOQ) calculated using the method developed by Limam et al. (2010). The method of Limam et al. allows an analysis of compounds via the headspace solid-phase micro-extraction (HSSPME) coupled with gas chromatography mass spectrometry (GC-MS), which were also used in the present study. Concentrations chosen for the chlorophenols are slightly greater than the average concentrations found in leachate because the concentrations reported in the literature are significantly lower than the LOQ.

\subsubsection{Preparation of solutions}

Prior to performing the experiment, a stock solution of the 13 phenolic compounds dissolved in methanol was prepared with a concentration 1000 times greater than the concentration in the solution used for the diffusion experiments (see Table 3). In a volumetric flask, $0.001 \mathrm{~g}$ of each chlorophenol was mixed with methanol to obtain $100 \mathrm{ml}$ of the stock solution, which was then stored at $-20^{\circ} \mathrm{C}$. To obtain the desired concentration in diffusion experiments $(10 \mu \mathrm{g} / 1$ for each chlorophenol as shown in Table 3$)$, the stock solution was diluted with deionised distilled water (DDW). The resulting source solution was used both in the source of the diffusion cells and for preparing standards for calibrating the gas chromatograph. The internal standard solution was prepared with 2,4,6-tricholorophenol ${ }^{13} \mathrm{C}^{6}$ and pentachlorophenol ${ }^{13} \mathrm{C}^{6}$, which are compounds containing isotopes of carbon $13\left({ }^{13} \mathrm{C}\right.$ ' to carbon 13).

\section{EXPERIMENTAL PROCEDURES}

\subsection{Batch-partitioning experiments}

\subsubsection{Experimental procedure}

Batch-partitioning experiments were performed at room temperature (i.e. $23 \pm 1^{\circ} \mathrm{C}$ ) in $120 \mathrm{ml}$ glass bottles equipped with screw-tight polytetrafluoroethylene (PTFE)lined caps for sampling. The experimental procedure was based on that of Islam and Rowe (2009). In preparing the PE films for batch-partitioning experiments, the films were cut into pieces $(30 \mathrm{~mm} \times 20 \mathrm{~mm}$ in average). According to Nefso and Burns (2007), cutting the films into smaller pieces does not affect the ultimate sorption capacity because the equilibrium between organic-pollutant and polymer sorption is a dissolution-controlled process, not a surface-controlled process.

Four bottles were used. Two of them, I1 and I2, contained $3 \mathrm{~g}$ of PE films cut in pieces and immersed in
$60 \mathrm{ml}$ of diffusion solution (solid/liquid ratio of $1 / 20$, as performed by Touze-Foltz et al. (2012)). The other two bottles, $\mathrm{C} 1$ and $\mathrm{C} 2$, were used for control experiments and contained only a solution identical to the one used in the diffusion tests (i.e. no PE films). A biocide agent (400 mg/ $1 \mathrm{HgCl}_{2}$ ) was added to all four bottles to limit the effects of biodegradation, as recommended by Touze-Foltz et al. (2012). Concentrations of the various chlorophenols were measured at the beginning $\left(t_{0}\right)$ and at the end $\left(t_{\mathrm{f}}\right)$ of the diffusion experiments to calculate the partition coefficient, $S_{\text {gf }}$.

\subsubsection{Calculation of partition coefficient}

The concentration of contaminant in the PE films, $c_{\mathrm{g}}$, and in solution, $c_{\mathrm{f}}$, are linked by Henry's Law

$$
c_{\mathrm{g}}=S_{\mathrm{gf}} c_{\mathrm{f}}
$$

where $S_{\mathrm{gf}}$ is the partition coefficient, which depends on temperature, fluid, PE film, and contaminant of interest. The partitioning coefficients $S_{\mathrm{gf}}$ were calculated for each bottle and each phenolic compound by using the following equation adapted from Sangam and Rowe (2001)

$$
S_{\mathrm{gf}}=\frac{\left[\left(c_{\mathrm{f} 0} V_{\mathrm{f} 0}\right) \cdot\left(1 p_{\mathrm{s}}\right)-c_{\mathrm{fF}} V_{\mathrm{fF}}-\sum c_{\mathrm{i}} V_{\mathrm{i}}\right] \rho_{\mathrm{g}}}{M_{\mathrm{g}} c_{\mathrm{fF}}}
$$

where $c_{\mathrm{f} 0}$ and $c_{\mathrm{fF}}$ are the initial and final concentrations of the solution in $\mathrm{g} / \mathrm{l}$, respectively, $V_{\mathrm{fo}}$ and $V_{\mathrm{fF}}$ are the initial and final volumes of the solution in litres, respectively, $p_{\mathrm{s}}$ is the proportion of contaminant sorbed onto the glass as determined based on the evolution of the concentration in bottles $\mathrm{C} 1$ and $\mathrm{C} 2$ and which is assumed to be independent of whether or not a PE film is present, $\rho_{\mathrm{g}}$ is the density in $\mathrm{g} / \mathrm{l}$ of the PE films, and $M_{\mathrm{g}}$ is the initial mass in grams of the PE films in bottles I1 and I2. Although a film was studied instead of a geomembrane, the subscript ' $g$ ' was used instead of ' $f$ ' to be consistent with the notation used in previous publications of diffusion studies.

\subsection{Diffusion experiment}

\subsubsection{Apparatus}

The apparatus, shown in Figure 2, consists of two independent cylindrical glass chambers similar to (although smaller than) the diffusion-experiment apparatus previously used by Touze-Foltz et al. $(2011,2012)$ to test geomembranes. Diffusion-experiment apparatus for geomembranes have an internal diameter of $0.12 \mathrm{~m}$ and the volume of each chamber is 0.731 . For PE films, the internal diameter is $0.10 \mathrm{~m}$ and the volume of each 


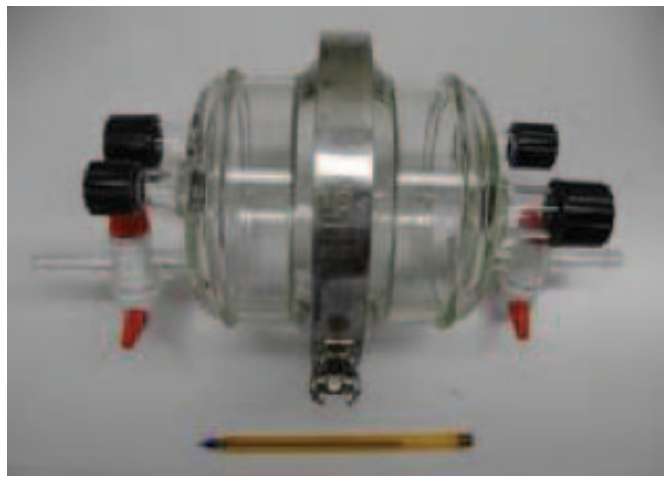

Figure 2. Diffusion cell

chamber is $0.44 \mathrm{~L}$. These reduced dimensions were imperative because it was not possible to obtain larger PE films with the fabrication method adopted (described in Section 2.1.1).

The specimen of PE film (Figure 1) was placed between the two chambers of the diffusion-experiment apparatus, which were then assembled by a metallic screw clamp, making for a very quick setup time for the experimental device. No sealant or o-ring was used. Each film was in direct contact with the glass cell on both sides. Each chamber contained a sampling port with a PTFE cap and a second port that could be used to fill the cell.

The same diffusion apparatus was used as a control cell in blank experiments (i.e. with no PE film) to assess the mass loss due to sorption onto the glass cell. The blank experiments were performed in parallel with the diffusion experiments. No stirring was used.

\subsubsection{Experimental procedure}

A permeation-diffusion method in which a PE film divides a diffusion-experiment cell into two compartments (source chamber and receptor chamber) was used because, compared with immersion-sorption experiments, such a method simulates more closely the transport process expected to occur in a landfill application (Sangam and Rowe 2001).

The PE film specimens were placed between the chambers of the diffusion cell and the following procedure was used for both virgin and aged specimens: (i) the receptor chamber of the diffusion cell was filled with DDW; (ii) the source chamber of the diffusion cell was filled with the previously prepared diffusion solution containing chlorophenols; (iii) in both chambers, $400 \mathrm{mg} / 1$ of a biocide agent $\left(\mathrm{HgCl}_{2}\right)$ was added to minimise biodegradation of the phenolic compounds; and (iv) the cells were covered with aluminium sheets to avoid photodegradation of the phenolic compounds. The experimental configuration ensured that there was no hydraulic gradient. The experiments were performed in duplicates at $23 \pm 1{ }^{\circ} \mathrm{C}$ in glass cells.

The solutions were immediately sampled to establish the initial concentrations of each phenolic compound in the source and receptor chambers. Subsequent samplings were performed at regular time intervals from both the source and receptor chambers. Samples were taken by inserting a syringe through the PTFE-lined septum of the sampling ports.

\subsubsection{Calculation of diffusion coefficient}

The diffusion of organic compounds through PE films can be modelled by Fick's first law

$$
f=-D_{\mathrm{g}} \frac{\mathrm{d} c_{\mathrm{g}}}{\mathrm{d} z}
$$

where $f$ is the mass flux or permeation rate per unit area $\left(\mathrm{g} / \mathrm{m}^{2}\right.$ per $\left.\mathrm{s}\right), D_{\mathrm{g}}$ is the diffusion coefficient of organic compounds through the film $\left(\mathrm{m}^{2} / \mathrm{s}\right), c_{\mathrm{g}}$ is the concentration of compound in the PE film $(\mathrm{g} / \mathrm{l})$, and $z$ is the distance parallel to the direction of diffusion $(\mathrm{m})$.

According to Fick's second law, the change with time $t$ in contaminant concentration at any point in the PE film is governed by the differential equation

$$
\frac{\partial c_{\mathrm{g}}}{\partial t}=D_{\mathrm{g}} \frac{\partial^{2} c_{\mathrm{g}}}{\partial z^{2}}
$$

The experimental procedure was based on concepts and theory proposed for geomembranes by Rowe et al. (1995), Sangam and Rowe (2001) and Islam and Rowe (2009). For these closed systems, the mass of contaminant in the source solution at any time $t$ equalled the initial mass minus the mass that diffused through the PE film. This can be expressed as

$$
c_{t}(t)=c_{0}-\frac{1}{H_{\mathrm{s}}} \int_{0}^{1} f_{\mathrm{t}}(\tau) \mathrm{d} \tau
$$

where $c_{t}(\mathrm{t})$ is the concentration in $\mathrm{g} / \mathrm{l}$ of contaminants in the source solution at time $t, c_{0}$ is the initial concentration in $\mathrm{g} / \mathrm{l}$ in the source solution, $H_{\mathrm{s}}$ is the height in metres of the source fluid (volume of source fluid per unit area), and $f_{t}(\tau)$ is the mass flux in $\mathrm{g} / \mathrm{m}^{2}$ per $\mathrm{s}$ of contaminant into the PE film at time $\tau$. The concentration $c_{\mathrm{b}}(t)$ in the receptor compartment at any time can be expressed as

$$
c_{\mathrm{b}}(t)=c_{\mathrm{b} 0}-\frac{1}{H_{\mathrm{b}}} \int_{0}^{1} f_{\mathrm{b}}(\tau) \mathrm{d} \tau
$$

where $c_{\mathrm{b} 0}(t)$ is the initial concentration in $\mathrm{g} / \mathrm{l}$ in the receptor solution, $H_{\mathrm{b}}$ is the height in metres of the receptor (volume of receptor chamber per unit area), and $f_{\mathrm{b}}(\tau)$ is the mass flux in $\mathrm{g} / \mathrm{m}^{2}$ per $\mathrm{s}$ of contaminant into the receptor chamber at any time $\tau$.

The diffusion coefficient $D_{\mathrm{g}}$ and partition coefficient $S_{\mathrm{gf}}$ were deduced following the procedure described by Sangam and Rowe (2001) by using the finite-layer analysis program POLLUTE v6 (Rowe and Booker 1997).

\subsection{Analytical methods}

The concentrations of phenolic compounds were quantified by HS-SPME-GC-MS according to the analytical method developed by Limam et al. (2010). The GC-MS (trace GC and DSQ, Dual-Stage quadrupole, Thermo Fischer) was equipped with a Combi PAL autosampler 
(CTC Analytics) allowing automatic SPME extraction. The GC split-splitless injector was used in splitless mode. The chromatographic column was a Zebron 5 MS column (5\% phenyl-methylpolysiloxane, Phenomenex, $60 \mathrm{~m}$ length, $0.25 \mathrm{~mm}$ inner diameter, $0.25 \mu \mathrm{m}$ film thickness). Chromatographic separation was performed using the following eight temperature stages: (1) $40^{\circ} \mathrm{C}$ for $5 \mathrm{~min}$; (2) an increase to $115^{\circ} \mathrm{C}$ at $15^{\circ} \mathrm{C} / \mathrm{min}$; (3) an increase to $175^{\circ} \mathrm{C}$ at $3^{\circ} \mathrm{C} / \mathrm{min}$; (4) $175^{\circ} \mathrm{C}$ for $5 \mathrm{~min}$; (5) an increase to $250^{\circ} \mathrm{C}$ at $30^{\circ} \mathrm{C} / \mathrm{min}$; (6) $250^{\circ} \mathrm{C}$ for $2 \mathrm{~min}$; (7) an increase to $280^{\circ} \mathrm{C}$ at $30^{\circ} \mathrm{C} / \mathrm{min}$; and $(8) 280^{\circ} \mathrm{C}$ for $5 \mathrm{~min}$. The injector temperature was held at $250^{\circ} \mathrm{C}$ and the splitless time was $5 \mathrm{~min}$. Helium was used as carrier gas with a column flow rate of $1.1 \mathrm{ml} / \mathrm{min}$. The Xcalibur software from Thermo Fisher was used for online data acquisition and processing. The fibre consisted of a $100 \mu \mathrm{m}$ polydimethylsiloxane (PDMS) from Supelco. As internal standard for quantification, 4,6-trichlorophenol- ${ }^{13} \mathrm{C}$, was used for 4-CP, 2,4-DCP, and 2,4,6-TCP and pentachlorophenol${ }^{13} \mathrm{C}^{6}$ was used for $2,3,5,6-\mathrm{TeCP}$ and PCP.

The quantification procedure involved two steps: derivatisation and headspace extraction. The derivatisation step consisted of adding $2 \mathrm{~g}$ of sodium chloride $(\mathrm{NaCl})$ $(40 \% \mathrm{~W} / \mathrm{V}), 200 \mathrm{mg}$ of potassium bicarbonate $\left(\mathrm{KHCO}_{3}\right)$, and $30 \mu \mathrm{l}$ of anhydride acetic acid $\left[\left(\mathrm{CH}_{3} \mathrm{CO}\right)_{2} \mathrm{O}\right]$ into a $20 \mathrm{ml}$ PTFE-capped glass vial containing $5 \mathrm{ml}$ of aqueous sample. The sodium chloride saturates the solution, which permits the phenolic compounds to pass easily into the gas phase, thereby improving the sensitivity of the analysis. The sodium bicarbonate $\left(\mathrm{KHCO}_{3}\right)$ avoids degradation of the phenolic compounds that would otherwise result from the addition of anhydride acetic acid $\left[\left(\mathrm{CH}_{3} \mathrm{CO}\right)_{2} \mathrm{O}\right]$. The sequence in which these reagents are added is essential because introducing the anhydride acetic acid $\left[\left(\mathrm{CH}_{3} \mathrm{CO}\right)_{2} \mathrm{O}\right]$ first could lead to an underestimate of compound concentration. To complete the derivation reaction, a $5 \mathrm{~min} 80^{\circ} \mathrm{C}$ pre-incubation period was necessary.

Pre-incubation was followed by extraction with the SPME fibre covered with a $100 \mu \mathrm{m}$ thick PDMS film at $80^{\circ} \mathrm{C}$ for $30 \mathrm{~min}$ under agitation $(500 \mathrm{rpm})$. Injection into the $\mathrm{GC}$-MS was performed at $250^{\circ} \mathrm{C}$, lasted $5 \mathrm{~min}$, and led to desorption of phenolic compounds from the fibre in the injector. Phenolic compounds were quantified by using the single-ion monitoring mode (SIM). Ion $\mathrm{m} / \mathrm{z}=128,162$, 196, 232, and 266 were used for 4-CP; 2,4-DCP; 2,4,6TCP; 2,3,5,6-TeCP; and PCP, respectively.

\section{RESULTS}

\subsection{Control cell}

To access the mass loss due to sorption onto the glass cell, a blank diffusion experiment was conducted using the diffusion apparatus with no specimen. The experiment was performed at the same time as the diffusion experiments. Figure 3 presents the temporal evolution of the concentrations (normalised with respect to initial concentration) in blank diffusion experiments. The concentration decrease due to sorption was negligible for all chlorophenols studied.

\subsection{Partitioning experiments}

Following the methodology described in Section 3.1, the partition coefficients $S_{\mathrm{gf}}$ for each phenolic compound were calculated with the assumption that the mass loss onto glass would occur even in the presence of a PE film. The corresponding partition coefficients are given in Table 4, which shows that the coefficients obtained for aged PE films are greater than those for virgin films.

\subsection{Diffusion experiments}

Figures $4 \mathrm{a}$ and $\mathrm{b}$ show the temporal variation in concentration (normalised by initial concentration) of chlorophenols in the source and the receptor chambers, respectively, for virgin PE films. A single evaluation of the concentration by GC-MS was done for each PE film specimen, and the average of two such measurements produced the data shown in Figure 4. Figures $5 \mathrm{a}$ and $\mathrm{b}$ show the temporal variation in concentration of chlorophenols in experiments

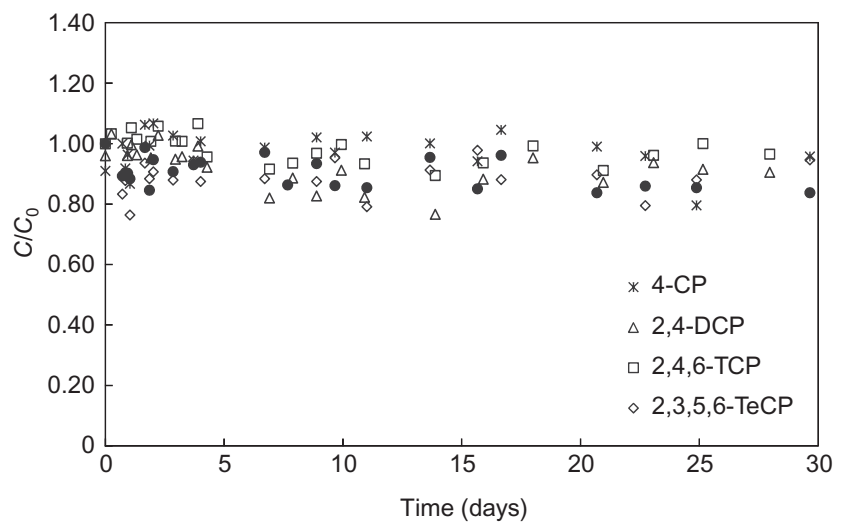

Figure 3. Normalised concentrations of chlorophenols in control cells for diffusion experiments

Table 4. Inferred partitioning and diffusion coefficients calculated from diffusion experiments

\begin{tabular}{|c|c|c|c|c|c|c|}
\hline \multirow[t]{2}{*}{ Compound } & \multicolumn{3}{|c|}{ Virgin PE film } & \multicolumn{3}{|c|}{ Aged PE film } \\
\hline & $\begin{array}{l}S_{\mathrm{gf}} \\
(-)\end{array}$ & $\begin{array}{c}D_{\mathrm{g}} \\
\left(\times 10^{-12} \mathrm{~m}^{2} / \mathrm{s}\right)\end{array}$ & $\left(\times 1 P_{\mathrm{g}}^{-12} \mathrm{~m}^{2} / \mathrm{s}\right)$ & $\begin{array}{l}S_{\mathrm{gf}} \\
(-)\end{array}$ & $\begin{array}{c}D_{\mathrm{g}} \\
\left(\times 10^{-12} \mathrm{~m}^{2} / \mathrm{s}\right)\end{array}$ & $\begin{array}{c}P_{\mathrm{g}} \\
\left(\times 10^{-12} \mathrm{~m}^{2} / \mathrm{s}\right)\end{array}$ \\
\hline 4-CP & 0.68 & 0.10 & 0.068 & 1.67 & 0.15 & 0.25 \\
\hline 2,4-DCP & 3.19 & 0.27 & 0.861 & 15.93 & 0.08 & 1.27 \\
\hline 2,4,6-TCP & - & - & - & 78.52 & 0.04 & 3.14 \\
\hline $2,3,5,6-\mathrm{TeCP}$ & 48.2 & 0.07 & 3.37 & 140.9 & 0.04 & 5.64 \\
\hline PCP & 278 & 0.01 & 2.78 & - & - & \\
\hline
\end{tabular}




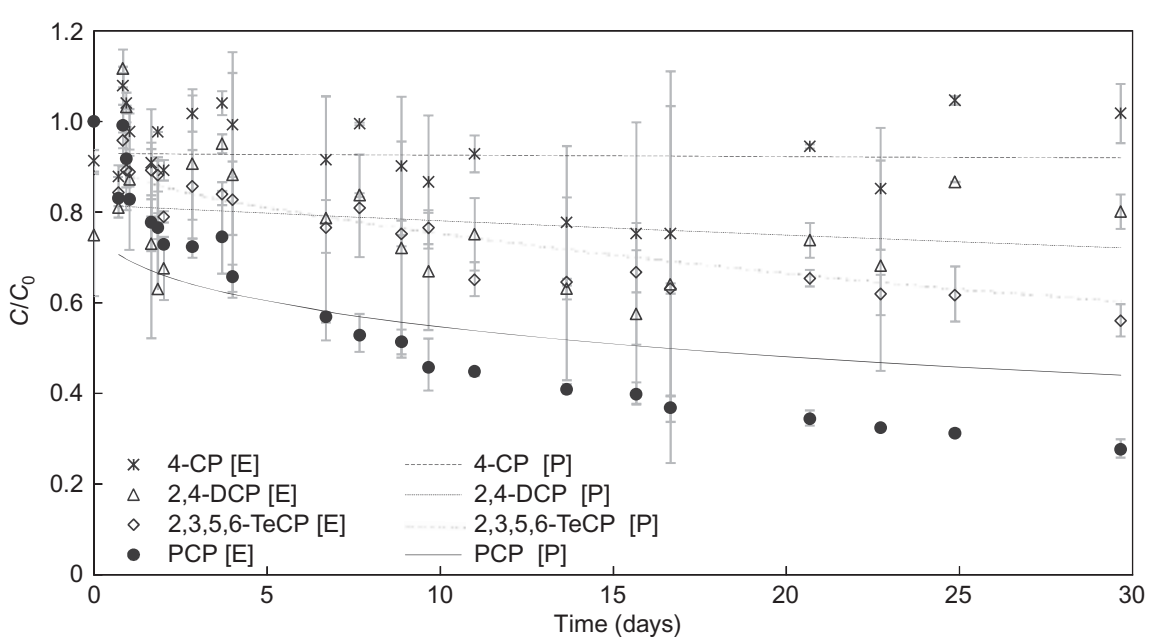

(a)

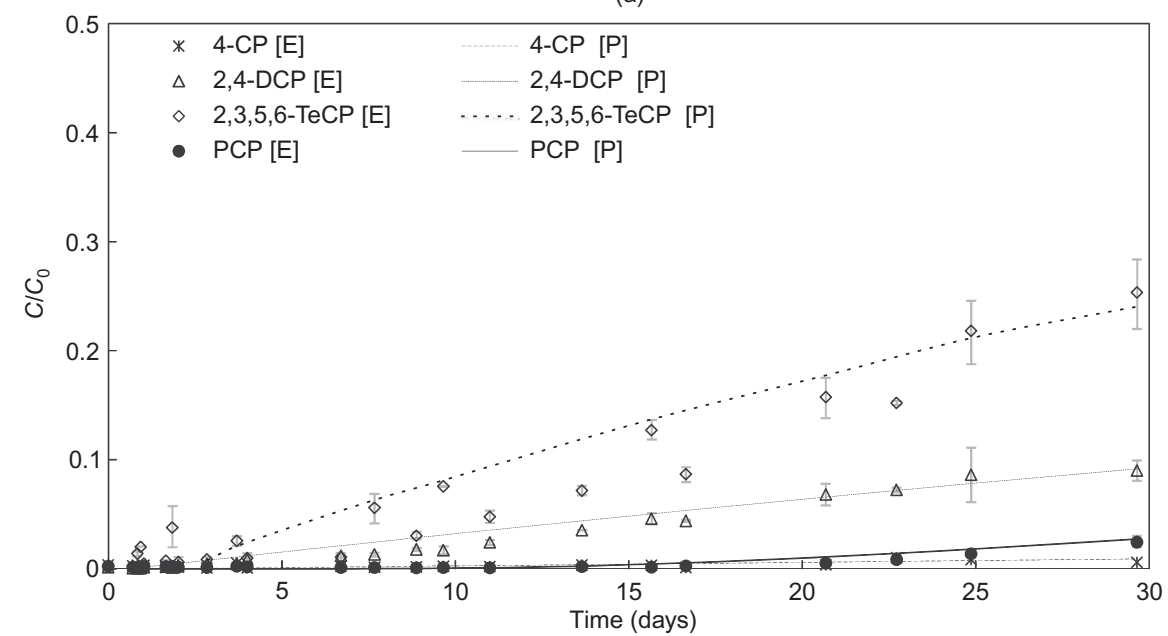

(b)

Figure 4. Temporal evolution of chlorophenols concentrations in: (a) source, and (b) receptor for virgin PE films

with aged PE films. The data for aged PE films correspond to a single film specimen. The experimental data are identified by ' $\mathrm{E}$ ' in the figures. Figures 4 and 5 also show the theoretical curves, which are identified by ' $\mathrm{P}$ '. These curves were generated by numerically solving the diffusion equation (Equations 5 and 6) for the partitioning coefficient previously determined (using Equation 2). The data presented are those corresponding to data which could be interpreted.

The diffusion coefficients thus determined range from $1 \times 10^{-14}$ to $2.7 \times 10^{-13} \mathrm{~m}^{2} / \mathrm{s}$ for virgin $\mathrm{PE}$ films and from $4 \times 10^{-14}$ to $1.5 \times 10^{-13} \mathrm{~m}^{2} / \mathrm{s}$ for aged $\mathrm{PE}$ films (Table 4). The permeation coefficients determined for the virgin specimens range from $7 \times 10^{-14} \mathrm{~m}^{2} / \mathrm{s}$ for $4-\mathrm{CP}$ to $3.13 \times 10^{-12} \mathrm{~m}^{2} / \mathrm{s}$ for $2,4,5,6-\mathrm{TeCP}$. For the aged specimens, the permeation coefficients range from $2.5 \times$ $10^{-13} \mathrm{~m}^{2} / \mathrm{s}$ for $4-\mathrm{CP}$ to $5.21 \times 10^{-12} \mathrm{~m}^{2} / \mathrm{s}$ for $2,4,5,6-\mathrm{TeCP}$.

\section{DISCUSSION}

\subsection{Influence of chlorine atoms on diffusion parameters}

5.1.1. Partition coefficient $\mathrm{S}_{\mathrm{gf}}$

An analysis of the results obtained indicates that the partition coefficient is closely linked to the degree of substitution of chlorine atoms on the phenolic nucleus. For both virgin and aged PE films, larger numbers of chlorine atoms correspond to larger partition coefficients. This phenomenon is most likely due to the difference in polarity of the chlorophenols, as previously noted by Touze-Foltz et al. (2012).

\subsubsection{Diffusion coefficient}

For both virgin and aged PE films, diffusion coefficients generally decrease with increasing number of chlorine atoms. However, an exception occurs for virgin PE film for $4 \mathrm{CP}$ and 2,4-DCP.

\subsection{Influence of ageing}

The diffusion coefficients increased from $1.0 \times 10^{-13} \mathrm{~m}^{2} / \mathrm{s}$ to $1.5 \times 10^{-13} \mathrm{~m}^{2} / \mathrm{s}$ for $4-\mathrm{CP}$ but decreased from $2.7 \times 10^{-13} \mathrm{~m}^{2} / \mathrm{s}$ to $0.8 \times 10^{-13} \mathrm{~m}^{2} / \mathrm{s}$ for $2,4-\mathrm{DCP}$ and from $0.7 \times 10^{-13} \mathrm{~m}^{2} / \mathrm{s}$ to $0.4 \times 10^{-13} \mathrm{~m}^{2} / \mathrm{s}$ for $2,3,5,6 \mathrm{TeCP}$. On the overall diffusion coefficients are smaller for aged specimens than for virgin specimens. Indeed the maximum value was $1.5 \times 10^{-13} \mathrm{~m}^{2} / \mathrm{s}$ for aged specimens whereas for virgin specimens the maximum value was $2.7 \times 10^{-13} \mathrm{~m}^{2} / \mathrm{s}$ (Table 4 ). The increase in crystallinity caused by ageing of $\mathrm{PE}$ films can explain the reduction in the diffusion coefficients (by a factor of approximately 1.9) in PE films. The permeation coefficient of the film, $P_{\mathrm{g}}$, obtained as the 


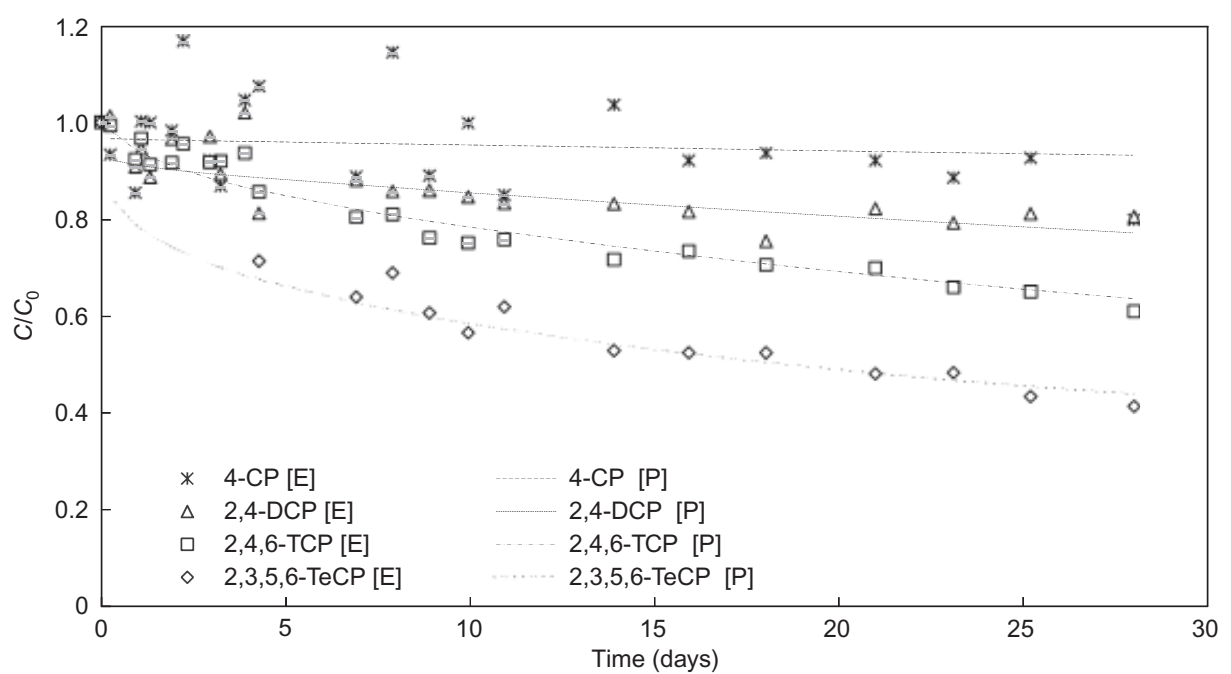

(a)

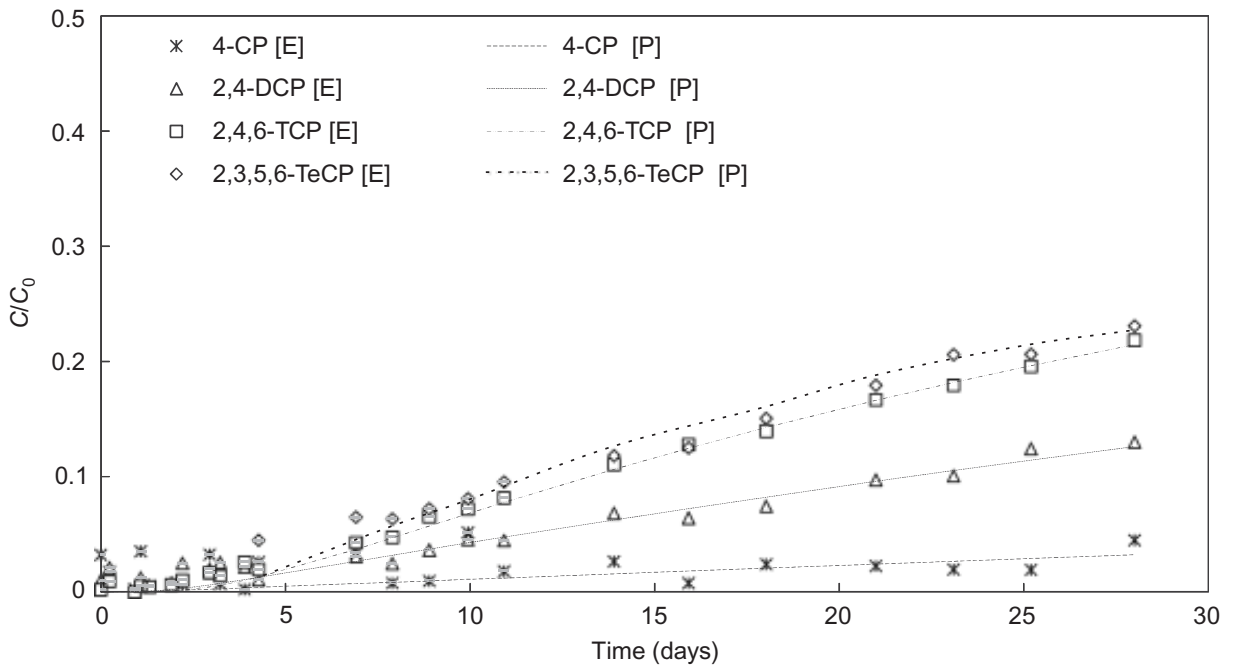

(b)

Figure 5. Temporal evolution of chlorophenols concentrations in: (a) source, and (b) receptor for aged PE films

product of $S_{\mathrm{gf}}$ and $D_{\mathrm{g}}$ increased in relation with ageing for those three contaminants from $6.8 \times 10^{-14} \mathrm{~m}^{2} / \mathrm{s}$ to $2.51 \times$ $10^{-13} \mathrm{~m}^{2} / \mathrm{s}$ for $4-\mathrm{CP}, 8.61 \times 10^{-13} \mathrm{~m}^{2} / \mathrm{s}$ to $1.27 \times$ $10^{-12} \mathrm{~m}^{2} / \mathrm{s}$ for $2,4-\mathrm{DCP}$ and from $3.37 \times 10^{-12} \mathrm{~m}^{2} / \mathrm{s}$ to $5.64 \times 10^{-12} \mathrm{~m}^{2} / \mathrm{s}$ for $2,3,5,6 \mathrm{TeCP}$. These results are opposite to those obtained by Rowe et al. (2003) upon comparing the diffusion coefficients of a new modern geomembrane with those of a 14-year-old geomembrane (both HDPE): Diffusion experiments performed with chlorinated hydrocarbons and aromatic hydrocarbons diffusion revealed that permeation coefficients for the virgin specimens were four to five times greater than those of the older specimens.

\subsection{Effect of pollutant properties on diffusion}

The partition coefficient (Figure 6) and diffusion coefficient (Figure 7) are plotted as a function of various chemical properties of the chlorophenols studied: the aqueous solubility $S$, the $n$-octanol-water partition coefficient, $K_{\mathrm{ow}}$, the molecular diameter, $d_{\mathrm{m}}$, and the molecular weight. The influence of these chemical properties on geomembrane diffusion parameters obtained from experiments with VOCs and phenolic compounds has been reported in the literature. Figures 6 and 7 show values from the literature together with values obtained from empirical equations and based on experimental data for VOCs. A compilation of existing empirical equations is presented in Table 5. Data of the diffusion of VOCs in HDPE geomembranes that were used to construct Figures 6 and 7 originate from Park and Nibras (1993), Prasad et al. (1994), Müller et al. (1998), Rowe (1998), Sangam and Rowe (2001), Rowe et al. (2003), Joo et al. (2004, 2005), Nefso and Burns (2007), Islam and Rowe (2009), TouzeFoltz et al. (2011) and Park et al. (2012). The work of Touze-Foltz et al. (2012) was used as the reference for the diffusion of phenolic compounds through an HDPE geomembrane.

\subsubsection{Partition coefficient $S_{\mathrm{gf}}$}

Figure 6 presents the partition coefficient $S_{\text {gf }}$ plotted as a function of $S, \log K_{\mathrm{ow}}, d_{\mathrm{m}}$, and molecular weight (Figures $6 \mathrm{a}$ to $\mathrm{d}$, respectively). The partition coefficient decreased with increasing aqueous solubility (Figure 6a) and with increasing $\log K_{\mathrm{ow}}$ (Figure 6b), which was expected because the less polar the contaminant, the less soluble it is in water.

These results are consistent with previous results 


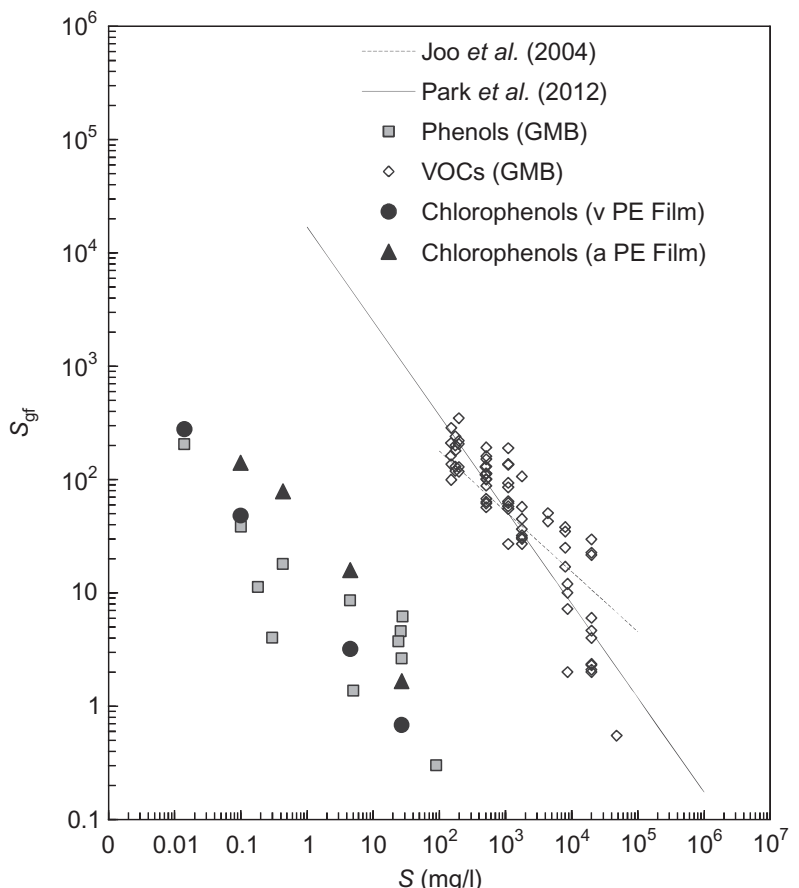

(a)

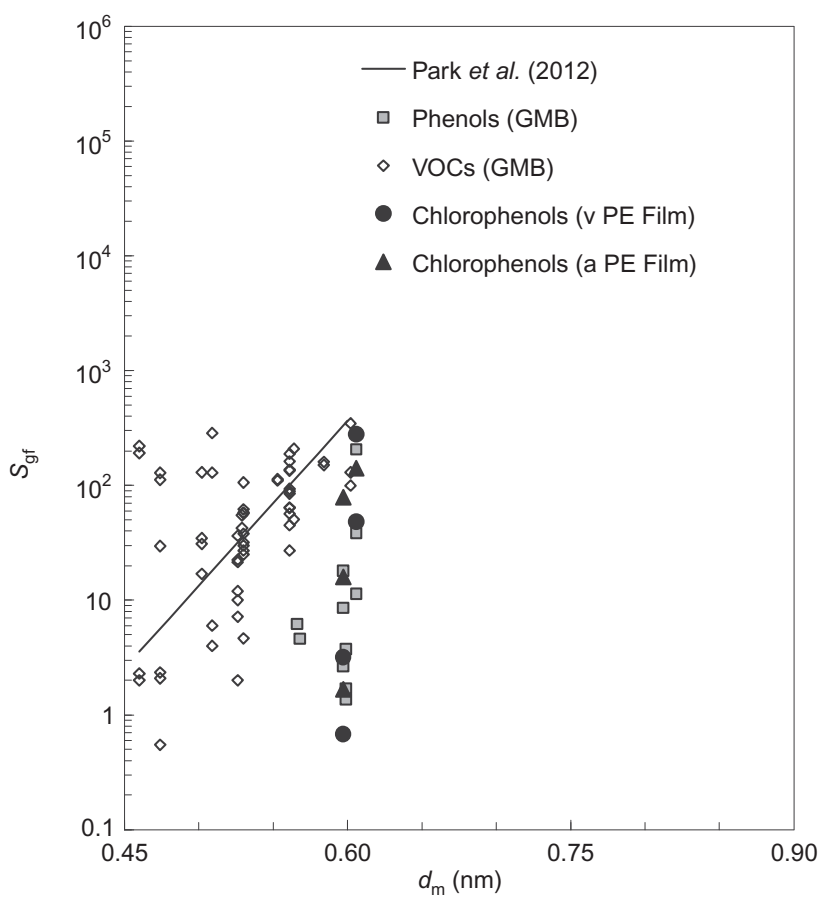

(c)

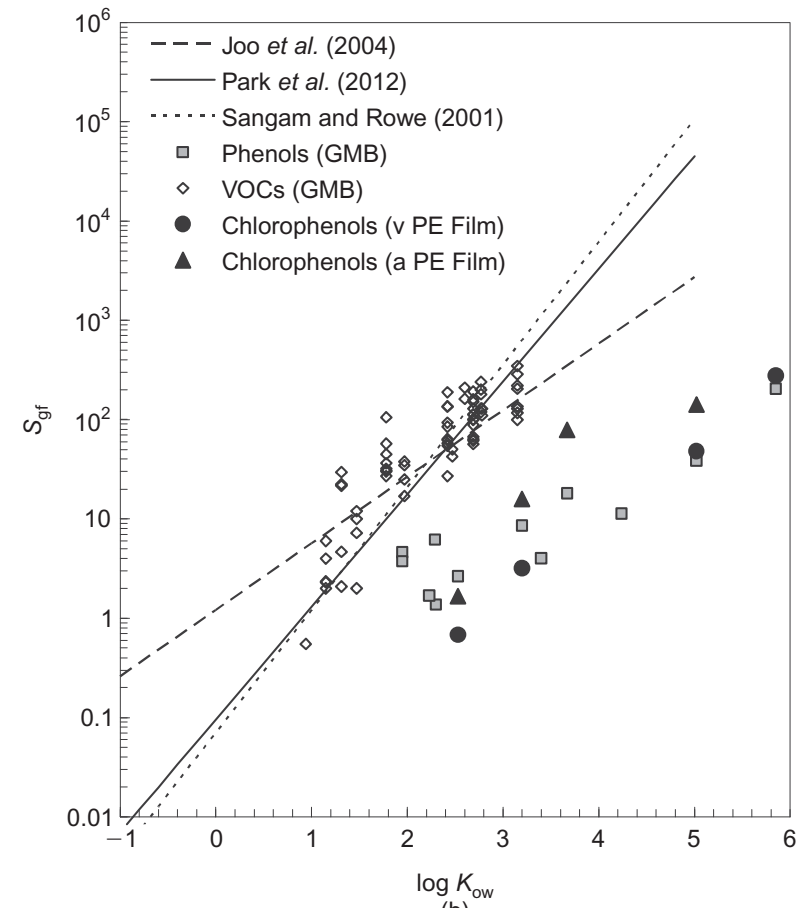

(b)

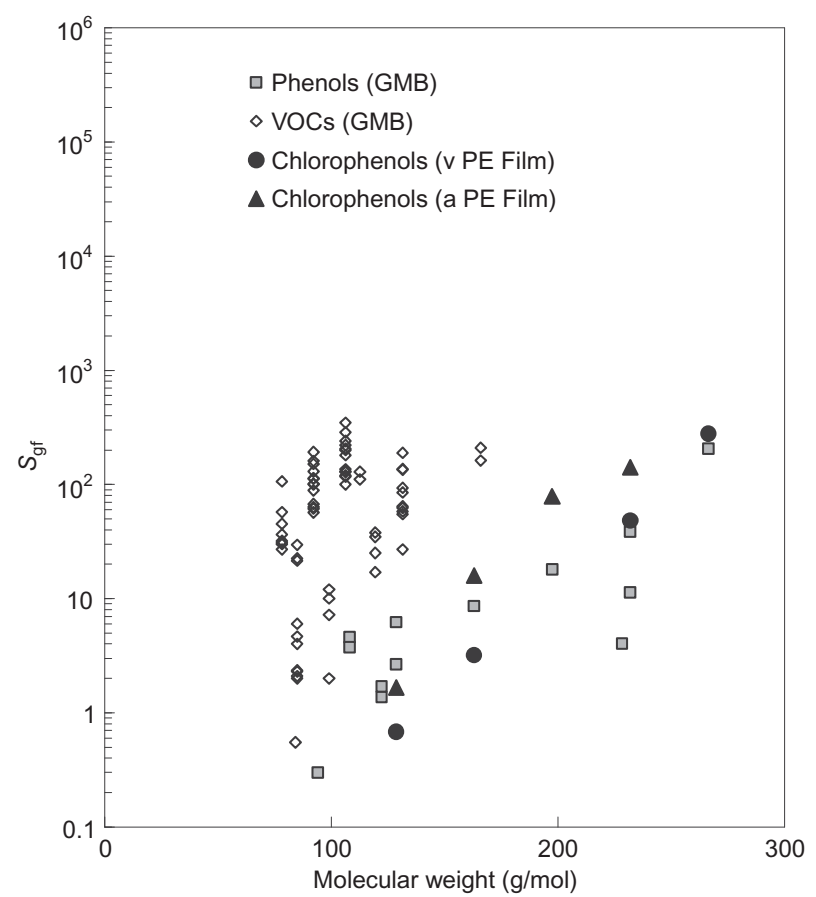

(d)

Figure 6. Partition coefficient $S_{\text {gf }}$ as a function of: (a) aqueous solubility $S$; (b) $n$-octanol-water partition coefficient $K_{\text {ow }}$; (c) molecular diameter $d_{\mathrm{m}}$; and (d) molecular weight for phenolic compounds and VOCs in diffusion experiments with geomembranes (results from the literature, see Section 4.4) and chlorophenols in diffusion experiments with PE films (results from present study) in virgin conditions (v PE film) and aged condition (a PE film)

obtained for the diffusion of phenolic compounds through HDPE geomembranes. The range of variations is similar, despite the ageing and the variations in geomembrane thickness. When one compares the range of values obtained for VOCs with those of phenolic compounds, it seems that the partition coefficient is much less influenced by ageing or thickness than by the chemical family of the diffusing compound.

No general trend was found for the partition coefficient as a function of molecular diameter (Figure 6c). For chlorophenols, molecular weight correlated well with partition coefficient (Figure 6d), a result that may be related to polarity.

\subsubsection{Diffusion coefficient}

Figures $7 \mathrm{a}$ to $\mathrm{d}$ present the diffusion coefficient $D_{\mathrm{g}}$ as a function of solubility, $\log K_{\mathrm{ow}}$, molecular diameter, and molecular weight, respectively. The diffusion coefficient 


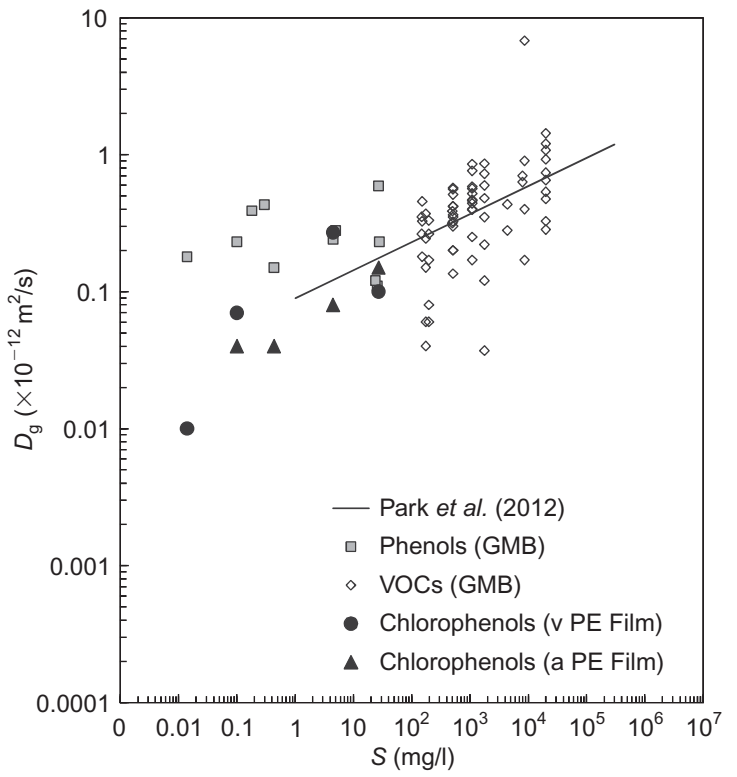

(a)

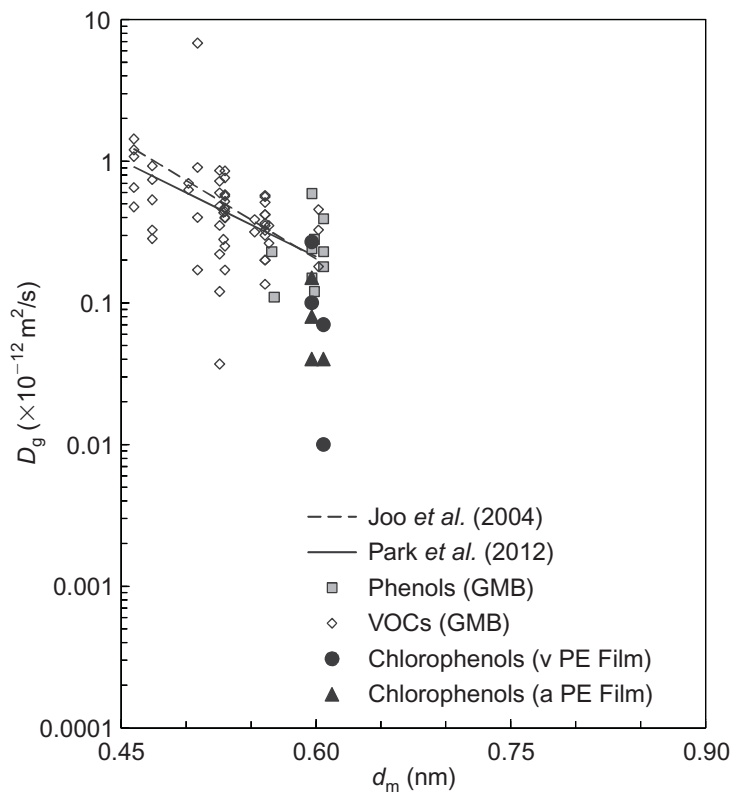

(c)

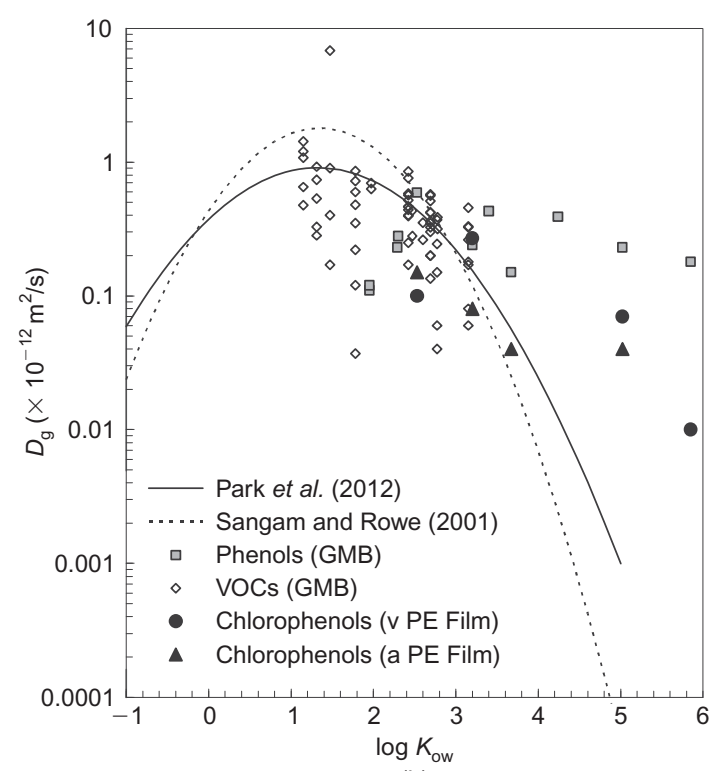

(b)

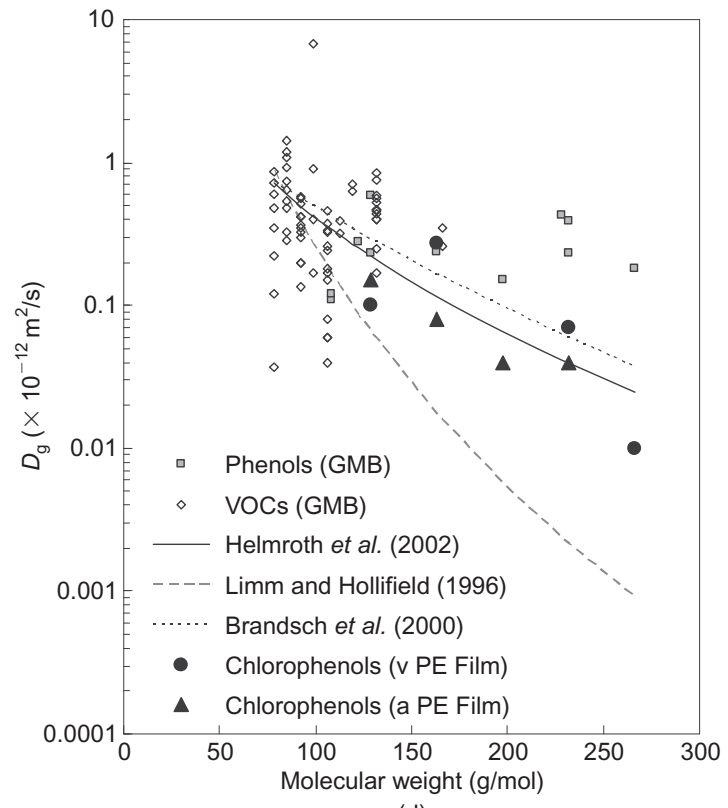

(d)

Figure 7. Diffusion coefficient $D_{\mathrm{g}}$ as function of (a) aqueous solubility, (b) $n$-octanol-water partition coefficient $K_{0 \mathrm{w}}$, (c) molecular diameter $d_{\mathrm{m}}$, and (d) molecular weight for phenolic compounds and VOCs in diffusion experiments with geomembranes (results from the literature, see Section 4.4) and chlorophenols in diffusion experiments with PE films (results from present study) in virgin conditions (v PE film) and aged condition (a PE film)

increases with increasing aqueous solubility (Figure 7a) and decreases with $\log K_{\mathrm{ow}}$ (Figure $7 \mathrm{~b}$ ), which is similar to the trends observed by Touze-Foltz et al. (2012) for the diffusion of phenolic compounds through geomembranes. However, more scatter is observed between data obtained for films and geomembranes than is the case for the partition coefficient. No general trend was found for the molecular diameter (Figure 7c). Touze-Foltz et al. (2012) noticed that, if BPA is excluded, previously given empirical equations (for VOCs) linking diffusion coefficient and molecular diameter would be acceptable for phenolic compounds. However, diffusion coefficients for the diffusion of chlorophenols through PE film do not follow the same trend. Figure $7 \mathrm{~d}$ shows that the diffusion coefficients decrease with increasing molecular weight for chlorophenols diffusing through PE films, which was not observed by Touze-Foltz et al. (2012) for phenolic compounds diffusing through geomembranes.

Bellili et al. (2012) provide an insight by using three molecular models to assess the diffusion coefficient. These three models, based on mathematical correlations between polymer type, diffusing substance molecular mass, and temperature, were previously combined by Helmroth et al. (2002) and used to predict the diffusion coefficient. Equations by Brandsch et al. (2000), Helmroth et al. (2002) and Limm and Hollifield (1996) are presented in Table 5. In Equation 18 in Table 5, $A_{\mathrm{p}}=8.8$ as given by Brandsch et al. (2000) because HDPE was used 
Table 5. Equations predicting partition coefficient, diffusion coefficient, and permeation coefficient

\begin{tabular}{|c|c|c|c|c|}
\hline \multicolumn{2}{|c|}{ Equation } & Parameters & \multirow{2}{*}{$\begin{array}{l}\text { Validity } \\
\text { HDPE } \\
\text { geomembranes }\end{array}$} & \multirow{2}{*}{$\begin{array}{l}\text { Source } \\
\text { Sangam and Rowe (2001) }\end{array}$} \\
\hline 7 & $\log S_{\mathrm{gf}}=1.2355 \log K_{\mathrm{ow}}-1.1523$ & & & \\
\hline 8 & $\log D=0.3424\left(\log K_{\mathrm{ow}}\right)^{2}+0.9205 \log K_{\mathrm{ow}}-12.3624$ & & & \\
\hline 9 & $\log S_{\mathrm{gf}}=0.670 \log K_{\mathrm{ow}}+0.084$ & & $\begin{array}{l}\text { HDPE } \\
\text { geomembranes }\end{array}$ & Joo et al. (2004) \\
\hline 10 & $\log S_{\mathrm{gf}}=-0.532 \log S+3.316$ & & & \\
\hline 11 & $\log D=-5.534 d_{\mathrm{m}}-9.368$ & & & \\
\hline 12 & $\log S_{\mathrm{gf}}=1.0614 \log K_{\mathrm{ow}}-0.8757$ & & $\begin{array}{l}\text { HDPE } \\
\text { geomembranes }\end{array}$ & \\
\hline 13 & $\log S_{\mathrm{gf}}=-0.8312 \log S+4.2291$ & & & \\
\hline 14 & $\log S_{\mathrm{gf}}=14.363 d_{\mathrm{m}}-6.0543$ & & & \\
\hline 15 & $\log D=-0.2283\left(\log K_{\mathrm{ow}}\right)^{2}+0.6166 \log K_{\mathrm{ow}}-12.4590$ & & VOCs & Park et al. (2012) \\
\hline 16 & $\log D=0.2049 \log S-13.0485$ & & & \\
\hline 17 & $\log D=-4.5119 d_{\mathrm{m}}-9.9659$ & & & \\
\hline 18 & $D=10^{4} \exp \left(A_{\mathrm{p}}-0.13 M^{2 / 3}-\frac{C+10450}{T}\right)$ & $\begin{array}{l}A_{\mathrm{p}}=8.8 \\
C=2315\end{array}$ & $\begin{array}{l}\text { Phenolic } \\
\text { compounds and } \\
\text { VOCs }\end{array}$ & Brandsch et al. (2000) \\
\hline 19 & $D=a \exp \left(-M^{\mathrm{b}}\right)$ & $\begin{array}{l}a=1.7 \times 10^{-10} \\
b=0.39\end{array}$ & & Helmroth et al. (2002) \\
\hline 20 & $D=D_{0} \exp \left(\alpha M^{0.5}-\frac{K M^{1 / 3}}{T}\right)$ & $\begin{array}{l}\alpha=0.819 \\
K=1760.7 \\
D_{0}=9.37 \times 10^{-5}\end{array}$ & $\begin{array}{l}\text { Food packaging } \\
\text { PE films }\end{array}$ & Limm and Hollifield (1996) \\
\hline
\end{tabular}

(understanding $A_{\mathrm{p}}$ as a characteristic structural parameter of the polymer which must be determined experimentally). To account for the effects of specific temperature effects on polymers the values of $C$, a polymer-specific parameter, are either 0 or 1577 , as recommended by Piringer and Baner (2000). The best fit was obtained by using $C=2315$. In fact, Bellili et al. (2012) suggest adjusting $A_{\mathrm{p}}$ and $C$ as required to obtain the best fit to experimental data. As suggested by Helmroth et al. (2002), Equation 19 in Table 5 was used with $b=0.39$ for HDPE, whereas $a$ was set to $1.7 \times 10^{-10}$ to obtain the best fit to the experimental data. Empirical constants $a$ and $b$ for Piringer's diffusion model are, respectively, an additive molecular weight-specific constant and a temperaturespecific constant. For Equation 20 in Table 5, by Limm and Hollifield (1996), $\alpha=0.819$ and $K=1760.7$ were used, as suggested by those authors for HDPE ( $\alpha$ is proportional to the slope of a plot of the diffusion coefficient as a function of the molecular weight square root; $K$ is a constant related to molecular weight). The parameter $D_{0}$ was set to $9.37 \times 10^{-5}$ to obtain the best fit to experimental data.

The minimum least square difference between the fits and experimental data was obtained with Equations 18 and 19 in Table 5. These equations seem to predict the order of magnitude of the diffusion coefficient over the entire range of molecular weights of VOCs and phenolic compounds tested to date. However, before using these equations as predictive tools it is necessary to check if they apply to other families of chemical compounds.

According to Helmroth et al. (2002), no currently available theories are sufficiently accurate to predict the evolution of the partition coefficient and the permeation coefficient as a function of molecular weight.

The diffusion parameters $\left(S_{\mathrm{gf}}\right.$ and $\left.D_{\mathrm{g}}\right)$ obtained from testing the diffusion of chlorophenols through virgin and aged PE films are the same order of magnitude as those obtained from experiments of phenolic compounds diffusing through geomembranes. To verify the validity of using $\mathrm{PE}$ films to investigate the effect of ageing on diffusion through HDPE geomembranes, it should be confirmed that these trends apply to other families of pollutants.

\section{CONCLUSION}

This paper presents experimental results of the diffusion through virgin and aged PE films of five chlorophenols (4-chlorophenol, 2,4-dichlorophenol, 2,4,6-trichlorophenol, 2,3,4,6-tetrachlorophenol, and pentachlorophenol). The aim of the present study was to determine any possible detrimental effect of ageing on the diffusion parameters of PE film. The results obtained in this work are also compared with published results for other compounds (VOCs and phenolic compounds) diffusing through HDPE geomembranes with the goal of verifying that the experiments performed with virgin and aged PE films are representative of diffusive transfer through virgin and aged HDPE geomembranes.

For PE films, the partition coefficients increase with an increasing number of chlorine atoms for chlorophenols whereas the diffusion coefficients generally decrease with increasing number of chlorine atoms.

For PE films, the diffusion coefficients decrease with the increase in crystallinity that occurs upon ageing. The permeation coefficient however increased contrarily to what was observed by Rowe et al. (2003) when they compared the diffusion of chlorinated and aromatic hydrocarbons through a new modern HDPE geomembrane compared with that through a 14-year-old HDPE geomembrane.

The results show that the partition coefficient is linked 
to the aqueous solubility and the $n$-octanol-water partition coefficient of the contaminant. In view of the results reported by Touze-Foltz et al. (2012), this latest result seems logical because less polar contaminants are less soluble in water. No clear evidence supports a link with the molecular diameter; however, for chlorophenols the molecular weight correlates well with the partition coefficient; a result that may be related to polarity.

An analysis of the chlorophenols under study (4-CP, 2,4-DCP, 2,4,6-TCP, 2,3,5,6-TeCP, and PCP) implies that the partition coefficient is closely linked with the degree of substitution of chlorine atoms on the phenolic nucleus - a phenomenon that may also be attributed to a difference in polarity between the various chlorophenols studied, as noticed by Touze-Foltz et al. (2012).

The diffusion coefficient and permeation coefficient correlate well with the aqueous solubility and the $n$ octanol-water partition coefficient of the chlorophenols. They also correlate well with the molecular diameter.

These trends are consistent with previous trends obtained for the diffusion of VOCs and phenolic compounds through geomembranes. However, the range of parameters obtained is significantly different, so the empirical equations published for VOCs cannot be used to predict the evolution of the partition coefficient of the chlorophenols studied herein and of the phenolic compounds studied by Touze-Foltz et al. (2012).

\section{ACKNOWLEDGEMENTS}

The study presented herein was funded by RGC\&U (C2D2) for the DURAGEOS research programme labelled by Axelera and Advancity, whose partners are IFSTTAR, IRSTEA, LTHE ENTPE, PIMM Arts et Métiers ParisTech, Suez-Environment, and Veolia Propreté. NAUE provided the polyethylene-octene pellets. The authors gratefully acknowledge the expert assistance in preparing the manuscript for publication from Dr Brett Kraabel of Physical Sciences Communication.

\section{NOTATION}

Basic SI units are shown in parentheses.

$A_{\mathrm{p}} \quad$ characteristic structural parameter of the polymer (dimensionless)

$a$ additive molecular weight-specific constant $\left(\mathrm{m}^{2} / \mathrm{s}\right)$

$b$ temperature-specific constant (dimensionless)

$C$ polymer specific parameter $(\mathrm{K})$

$c_{\mathrm{b}}$ concentration in receptor compartment at time $t(\mathrm{~kg} / \mathrm{l})$

$c_{\mathrm{fF}}$ final equilibrium solution concentration $(\mathrm{kg} / \mathrm{l})$

$c_{\mathrm{f} 0}$ initial solution concentration $(\mathrm{kg} / \mathrm{l})$

$c_{\mathrm{g}}$ concentration of diffusing substance in geomembrane $(\mathrm{kg} / \mathrm{l})$

$c_{i} \quad$ concentration at sampling event $i(\mathrm{~kg} / \mathrm{l})$ $c_{t}$ concentration in source solution at time $t$ $(\mathrm{kg} / \mathrm{l})$

$D_{\mathrm{g}}$ diffusion coefficient of geomembrane $\left(\mathrm{m}^{2} / \mathrm{s}\right)$

$f$ flux $\left(\mathrm{kg} / \mathrm{m}^{2} / \mathrm{s}\right)$

$f_{\mathrm{m}}$ flux of contaminant into receptor chamber at time $t\left(\mathrm{~kg} / \mathrm{m}^{2} / \mathrm{s}\right)$

$f_{t}$ flux of contaminant into geomembrane at time $t\left(\mathrm{~kg} / \mathrm{m}^{2} / \mathrm{s}\right)$

$H_{\mathrm{s}}$ volume of source fluid per unit area (m)

$K$ constant related to molecular weight $\left((\mathrm{mol} / \mathrm{g})^{1 / 3} \mathrm{~K}\right)$

M molecular weight $(\mathrm{kg} / \mathrm{mol})$

$M_{\mathrm{g}} \quad$ initial mass of geomembrane $(\mathrm{kg})$

$P_{\mathrm{g}}$ permeation coefficient of the geomembrane $\left(\mathrm{m}^{2} / \mathrm{s}\right)$

$p_{\mathrm{s}}$ proportion of contaminant sorbed onto glass (dimensionless)

$S_{\mathrm{gf}}$ partition coefficient of contaminant (dimensionless)

$t$ time (s)

$V_{\mathrm{fF}}$ final solution volume $\left(\mathrm{m}^{3}\right)$

$V_{\mathrm{f} 0}$ initial solution volume $\left(\mathrm{m}^{3}\right)$

$V_{i} \quad$ volume at sampling event $i\left(\mathrm{~m}^{3}\right)$

$z$ position in geomembrane $(\mathrm{m})$

$\alpha$ parameter proportional to the slope of a plot of the diffusion coefficient in function of the molecular weight square $\operatorname{root}\left((\mathrm{mol} / \mathrm{g})^{0.5}\right)$

$\rho_{\mathrm{g}}$ geomembrane density $\left(\mathrm{kg} / \mathrm{m}^{3}\right)$

\section{ABBREVIATIONS}

LOD limit of detection

PCP pentachlorophenol

2,4-DCP 2,4-dichlorophenol

2,4,6-TCP 2,4,6-trichlorophenol

2,3,5,6-TeCP 2,3,5,6-tetrachlorophenol

4-CP 4-chlorophenol

\section{REFERENCES}

Ahari, M., Touze-Foltz, N., Mazéas, L. \& Guenne, A. (2011). Quantification of the adsorption of phenolic compounds on the geotextile and bentonite components of four geosynthetic clay liners. Geosynthetics International, 18, No. 5, 322-331.

Ahel, M. \& Tepic, N. (2000). Distribution of polycyclic aromatic hydrocarbons in a municipal solid waste landfill and underlying soil. Bulletin of Environmental Contamination and Toxicology, 65, No. 2, 236-243.

Banat, F., Al-Bashir, B., Al-Asheh, S. \& Hayajneh, O. (2000). Adsorption of phenol by bentonite. Environmental Pollution, 107, No. 3, 391398.

Bauer, M. J. \& Herrmann, R. (1997). Estimation of the environmental contamination by phthalic acid esters leaching from household wastes. The Science of the Total Environment, 208, No. 1-2, 49-57.

Baun, A., Ledin, A., Reitzel, L. A., Bjerg, P. L. \& Christensen, T. H. (2004). Xenobiotic organic compounds in leachates from ten Danish MSW landfills - chemical analysis and toxicity tests. Water Research, 38, No. 8, 3845-3858.

Behnisch, P. A., Fujii, K., Shiozaki, K., Kawakami, I. \& Sakai, S. (2001). 
Estrogenic and dioxin-like potency in each step of a controlled landfill leachate treatment plant in Japan. Chemosphere, 43, No. 47, 977-984.

Bellili, A., David, N., Vandame, B., Wang, Q., Goutille, Y. \& Richaud, E. (2012). Diffusion and solubility of mineral oils through ethylenevinyl acetate copolymer. Polymer Testing, 31, No. 2, 236-247.

Brandsch, J., Mercea, P. \& Piringer, O. (2000). Modeling of additive diffusion coefficients in polyolefins. Food Packaging: Testing Methods and Applications, Risch, S. J., Editor, ACS Symposium Series 753, American Chemical Society, Washington, DC, USA, pp. $27-36$.

Christensen, T. H., Kjeldsen, P., Bjerg, P. L., Jensen, D. L., Christensen, J. B., Baun, A., Albrechtsen, H. \& Heron, G. (2001). Biogeochemistry of landfill leachate plumes. Applied Geochemistry, 16, No. 7-8, $659-718$.

Cousins, I. T., Staples, C. A., Klecka, G. M. \& Mackay, D. (2002). A multimedia assessment of the environmental fate of bisphenol A. Human and Ecological Risk Assessment, 8, No. 5, 1107-1135.

Farcas, F., Touze-Foltz, N., Bouchez, T., Cardona, L., Durrieu, C., Fayolle, B., Lanoë, M., Martins, J., Mazéas, L., Mendes, M., Méry, J., Pierson, P., Pons, C., Richaud, E. \& Sablayrolles, M. (2013). Durabilité des géosynthétiques dans les installations de stockage des déchets. Rapport Final du projet DURAGEOS, IFSTTAR, Marne-la-Vallée, France (in French).

Gron, C., Christensen, J. B., Jensen, D., Kjeldsen, P. \& Ostfeldt, P. (1999). Organic halogens in landfill leachates. Water, Air, and Soil Pollution, 120, No. 3-4, 331-345.

Harmsen, J. (1981). Identification of organic compounds in leachate from a waste tip. Water Research, 17, No. 6, 699-705.

Helmroth, E., Rijk, R., Dekker, M. \& Jogen, W. (2002). Predictive modelling of migration from packaging materials into food products for regulatory purposes. Trends in Food Science \& Technology, 13, No. 3, 102-109.

Hiroshi, A., Toshihiko, M. \& Nobutoshi, T. (2002). Endocrine disrupters in leachate from two MSW landfills of different waste compositions in Japan. Proceedings of the 2nd Asian Pacific Landfill Symposium, Seoul 2002, pp. 728-736.

Islam, M. Z. \& Rowe, R. K. (2008). Effect of geomembrane aging on the diffusion of VOCs through HDPE geomembranes. Proceedings of the First Pan American Geosynthetics Conference \& Exhibition, Cancun, Mexico, pp. 459-467 (CD-ROM).

Islam, M. Z. \& Rowe, R. K. (2009). Permeation of BTEX through unaged and aged HDPE geomembranes. Journal of Geotechnology and Geoenvironmental Engineering, 135, No. 8, 1130-1140.

Joo, J. C., Kim, J. Y. \& Nam, K. (2004). Mass transfer of organic compounds in dilute aqueous solutions into high density polyethylene geomembranes. Journal of Environmental Engineering, 130, No. 2, 175-183.

Joo, J. C., Nam, K. \& Kim, J. Y. (2005). Estimation of mass transport parameters of organic compounds through high density polyethylene geomembranes using a modified double-compartment apparatus. Journal of Environmental Engineering, 131, No. 5, 790-799.

Koumanova, B. \& Peeva-Antova, P. (2002). Adsorption of $p$-chlorophenol from aqueous solutions on bentonite and perlite. Journal of Hazardous Materials, 90, №. 3, 229-234.

Kjeldsen, P., Barlaz, M. A., Rooker, A. P., Baun, A., Ledin, A. \& Christensen, T. H. (2002). Present and long-term composition of MSW landfill leachate: A review. Critical Reviews in Environmental Science and Technology, 32, No. 4, 297-336.

Kujawski, W., Waszawski, A., Ratajczak, W., Porebski, T., Capala, W. \& Ostrowska, I. (2004). Removal of phenol from wastewater by different separation techniques. Desalination, 163, No. 1-3, 287296.

Lee, M., Yeh, Y., Hsiang, W. \& Hwang, B. (1998). Solid-phase microextraction and gas chromatography mass spectrometry for determining chlorophenols from landfill leaches and soil. Journal of Chromatography A, 806, No. 2, 317-324.

Limam, I., Guenne, A., Driss, M. \& Mazeas, L. (2010). Simultaneous determination of phenol, methylphenols, chlorophenols and bisphenol-A by headspace solid-phase microextraction-gas chromatography-mass spectrometry in water samples and industrial effluents.
International Journal of Environmental Analytical Chemistry, 90, No. 3-6, 230-244.

Limm, W. \& Hollifield, H. C. (1996). Modelling of additives diffusion in polyolefins. Food Additives and Contaminants, 13, No. 8, 949967.

McWatters, R. S. \& Rowe, R. K. (2010). Diffusive transport of VOCs through LLDPE and two coextruded geomembranes. Journal of Geotechnical and Geoenvironmental Engineering, 136, No. 9, 1167-1177.

McWatters, R. S. \& Rowe, R. K. (2008). Transport of volatile organic compounds through PVC and LLDPE geomembranes from both aqueous and vapour phases. Geosynthetics International, 16, No. 6, $468-481$.

Mendes, M. J. A., Touze-Foltz, N., Gardoni, M., Guenne, A. \& Mazeas, L. (2013). Quantification of diffusion of phenolic compounds in virgin GCL and in GCL after contact with a synthetic leachate. Geotextiles and Geomembranes, 38, 16-25.

Müller, W., Jakob, R. \& Tatsky-Gerth August, H. (1998). Solubilities, diffusion and partitioning coefficients of organic pollutants in HDPE geomembranes: experimental results and calculations. Proceedings of the 6th International Conference on Geosynthetics, Rowe, R. K., Editor, Industrial Fabrics Association International, Roseville, MN, USA, vol. 1, pp. 239-248.

Nagasaki, S., Nakagawa, Y. \& Tanaka, S. (2004). Sorption of nonylphenol on Na-Montmorillonite. Colloids and Surfaces A: Physicochemical and Engineering Aspects, 230, No. 1-3, 131-139.

Nefso, E. K. \& Burns, S. E. (2007). Comparison of the equilibrium sorption of five organic compounds to HDPE, and PVC geomembranes. Geotextiles and Geomembranes, 25, No. 6, 360365.

Niederer, C. \& Goss, K. (2008). Effect of ortho-chlorine substitution on the partition behavior of chlorophenols. Chemosphere, 71, No. 4, $697-702$.

Nininen, M. \& Kalliokoski, P. (1994). Effect of organic contaminants in landfill leachates on groundwater quality in Finland. Groundwater Quality Management - Proceedings of the GQM 93 Conference, Kovar, K. \& Soveri, J., Editors, IAHS Press, Wallingford, UK, pp. $64-71$.

Oman, C. \& Hynning, P. A. (1993). Identification of organic compounds in municipal landfill leachates. Environmental Pollution, 80, No. 3, $265-271$.

Otero, M., Zabkova, M. \& Rodriguez, A. L. (2005). Adsorptive purification of phenol wastewaters: Experimental basis and operation of a parametric pumping unit. Chemical Engineering Journal, 110, No. 1-3, 101-111

Ozkaya, B. (2005). Chlorophenols in leachates originating from different landfills and aerobic composting plants. Journal of Hazardous Materials, 124, No. 1-3, 107-112.

Park, J. K. \& Nibras, M. (1993). Mass flux of organic chemicals through polyethylene geomembranes. Water and Environmental Research, 65, No. 3, 227-237.

Park, M., Benson, C. H. \& Edil, T. B. (2012). Comparison of batch and double compartment test for measuring volatile organic compound transport parameters in geomembranes. Geotextiles and Geomembranes, 31, 15-30.

Paxeus, N. (2000). Organic compounds in municipal landfill leachates. Water Science and Technology, 42, No. 7-8, 323-333.

Piringer, O.-G. \& Baner, A. L. (2000). Plastic packaging materials for food. Barrier Function, Mass Transport, Quality Assurance and Legislation, Weinheim and Wiley, New York, NY, USA.

Pons, C. (2012). Durabilité des géomembranes en polyéthylène haute densité utilisées dans les installations de stockage de déchets non dangereux. DSc thesis, Université Paris-Est, Paris, France (in French).

Pons, C., Farcas, F. \& Mkademi, H. (2012). Behavior of antioxidants in HDPE geomembranes used in municipal solid waste landfills. Eurogeo 2012, Valencia, Spain, 16-19 September 2012.

Prasad, T. V., Brown, K. W. \& Thomas, J. C. (1994). Diffusion coefficients of organics in high density polyethylene (HDPE). Waste Management and Research, 12, No. 1, 61-71.

Ramamoorthy, S. \& Ramamoorthy, S. (1997). Chlorinated Organic 
Compounds in the Environment, CRC Press, Boca Raton, FL, USA, $384 \mathrm{pp}$.

Reinhard, M. \& Goodman, N. L. (1984). Occurrence and distribution of organic chemicals in two landfill leachate plumes. Environmental Science \& Technology, 18, No. 12, 953-961.

Reitzel, L. A. \& Ledin, A. (2002). Determination of phenols in landfill leachate-contaminated groundwaters by solid-phase extraction. Journal of Chromatography A, 972, No. 2, 175-182.

Ribeiro, A., Neves, M. H., Almeida, M. F., Alves, A. \& Santos, L. (2002). Direct determination of chlorophenols in landfill leachates by solid-phase micro-extraction-gas chromatography-mass spectrometry. Journal of Chromatography A, 975, No. 2, 267-274.

Richards, S. \& Bouazza, A. (2007). Phenol adsorption in organomodified basaltic clay and bentonite. Applied Clay Science, 37, No. $1-2,133-142$.

Robinson, H. D., Knox, K., Van Santen, A. \& Tempany, P. R. (2001). Compliance of UK landfills with EU pollution emissions legislation: Development of a reporting protocol. Proceedings Sardinia 2001, Eighth International Waste Management and Landfill Symposium, Cagliari, Italy, 1-5 October 2001, pp. 21-30.

Rowe, R. K. (1998). Geosynthetics and the minimization of contaminant migration through barrier systems beneath solid waste. Proceedings of the 6th International Conference on Geosynthetics, Rowe, R. K., Editor, Industrial Fabrics Association International, Roseville, MN, USA, vol. 1, pp. 27-103.

Rowe, R. K. \& Booker, J. R. (1997). POLLUTE v. 6. 3: 1D Pollutant Migration Through a Non-Homogeneous Soil. Distributed by GAEA Environmental Engineering Ltd, Whitby, Ontario, Canada.

Rowe, R. K., Sangam, H. P. \& Lake, C. B. (2003). Evaluation of an HDPE geomembrane after 14 years as a leachate lagoon liner. Canadian Geotechnical Journal, 40, No. 3, 536-550.

Rowe, R. K., Hrapovic, L. \& Kosaric, N. (1995). Diffusion of chloride through an HDPE geomembrane. Geosynthetics International, 2, No. 3, 507-536.

Sangam, H. P. \& Rowe, R. K. (2001). Migration of dilute aqueous organic pollutants through HDPE geomembranes. Geotextiles and Geomembranes, 19, No. 6, 329-357.

Sangam, H. P. \& Rowe, R. K. (2005). Effect of surface fluorination on diffusion through a high density geomembrane. Journal of Geotechnical and Geoenvironmental Engineering, 131, No. 6, 694704.

Sawhney, B. L. \& Kozloski, R. P. (1984). Organic pollutants in leachates from landfill sites. Journal of Environmental Quality, 13, No. 3, $349-352$.

Schrab, G. E., Brown, K. W. \& Donnelly, K. C. (1993). Acute and genetic toxicity of municipal landfill leachate. Water, Air, and Soil Pollution, 69, No. 1-2, 99-112.

Schwarzbauer, J., Heim, S., Brinker, S. \& Littke, R. (2002). Occurrence and alteration of organic contaminants in seepage and leakage water from a waste deposit landfill. Water Research, 36, No. 9, 22752287.

Sisinno, L. S., Oliveira-Filho, E. C., Dufrayer, M. C., Moreira, J. C. \& Paumgartten, J. R. (2000). Toxicity evaluation of a municipal dump leachate using zebrafish acute tests. Bulletin of Environmental Contamination and Toxicology, 64, No. 1, 107-113.
Slack, R. J., Gronow, J. R. \& Voulvoulis, N. (2005). Household hazardous waste in municipal landfills: contaminants in leachate. Science of the Total Environment, 337, No. 1-3, 119-137.

Staples, C. A., Dorn, P. B., Kleska, G. M., O’Block, S. \& Harris, L. R. (1998). A review of the environmental, effects and exposures of bisphenol A. Chemosphere, 36, No. 10, 2149-2173.

Takigami, H., Matsui, S., Matsuda, T. \& Shimizu, Y. (2002). The Bacillus subtilis rec-assay: a powerful tool for the detection of genotoxic substances in the water environment. Prospect for assessing potential impact of pollutants from stabilized wastes. Waste Management, 22, No. 2, 209-213.

Touze-Foltz, N., Rosin-Paumier, S., Mazéas, L. \& Guenne, A. (2011). Diffusion of volatile organic compounds through an HDPE geomembrane. Geo-Frontiers 2011 - Advances in Geotechnical Engineering, Geotechnical Special Publication 211, Han J. \& Alzamora, D. E., Editors, American Society of Civil Engneers, Reston, VA, USA, pp. 1121-1130 (CD-ROM).

Touze-Foltz, N., Ahari, M., Mendes, M., Barral, C., Gardoni, M. \& Mazéas, L. (2012). Diffusion of phenolic compounds through an HDPE geomembrane. Journal of Geotechnical Engineering. South East Asia Geotechnical Engineering Society, 43, No. 3, 19-29.

Touze-Foltz, N., Mendes, M., Méry, J. \& Mazéas, L. (2013). Transfers of phenolic compounds through landfill bottom liners. Indian Geotechnical Journal, 43, No. 4, 367-381.

Van Praagh, M., Torneman, N., Johansson, M., Ingelstedt Frendberg, L. E., Heander, E. \& Johansson, A. (2011). Emerging organic contaminants in leachate - review and risk assessment. Sardinia 2011, Thirteenth International Waste Management and Landfill Symposium Proceedings, Cossu, R., He, P., Kjeldsen, P., Matsufuji, Y., Reinhart, D. \& Stegmann, R., Editors, CISA Publisher, Padova, Italy.

Verdu, J. (1984). Vieillissement des Plastiques, AFNOR Technique, Paris, France (in French).

Viraraghavan, T. \& Alfaro, F. M. (1998). Adsorption of phenol from wastewater by peat, fly ash and bentonite. Journal of Hazardous Materials, 57, No. 1-3, 59-70.

Yamada, K., Urase, T., Matsuo, T. \& Suzuki, N. (1999). Constituents of organic pollutants in leachates from different types of landfill sites and their fate in the treatment processes. Journal of Japan Society for Water Environment, 22, No. 1, 40-45.

Yamamoto, T., Yasuhara, A., Shiraishi, H. \& Nakasugi, O. (2001). Bisphenol A in hazardous waste landfill leachates. Chemosphere, 42, No. 4, 415-418

Yasuhara, A., Shiraishi, H., Nishikawa, M., Yamamoto, T., Uehiro, T., Nakasugi, O., Okumura, T., Kenmotsu, K., Fukui, H., Nagase, M., Ono, Y., Kawagoshi, Y., Baba, K. \& Noma, Y. (1997). Determination of organic components in leachates from hazardous waste disposal sites in Japan by gas chromatography mass spectrometry. Journal of Chromatography A, 774, No. 1-2, 321-332.

Yasuhara, A., Shiraishi, H., Nakasugi, O., Yamamoto, T., Nishikawa, M., Okumura, T., Kenmotsu, K., Fukui, H., Nagase, M. \& Kawagoshi, Y. (1999). Organic components in leachates from hazardous waste disposal sites. Waste Management \& Research, 17, No. 3, $186-197$.

Yu, J., Shin, M., Noh, J. \& Seo, J. (2004). Adsorption of phenol and chlorophenols on Ca-montmorillonite in aqueous solutions. Geosciences Journal, 8, No. 2, 185-189.

The Editor welcomes discussion on all papers published in Geosynthetics International. Please email your contribution to discussion@geosynthetics-international.com by 15 October 2014. 